\title{
Akademik Teşvik Tabanlı Yeni Bir Performans Değerlendirme Önerisi ve Uygulama
}

\author{
Mustafa Hamurcu', Tamer Eren ${ }^{2}$ \\ ${ }^{1}$ Kırıkkale üniversitesi, Mühendislik Fakültesi, Endüstri Mühendisliği Bölümü, hamurcu.mustafa@kku.edu.tr \\ ${ }^{2}$ Kırıkkale üniversitesi, Mühendislik Fakültesi, Endüstri Mühendisliği Bölümü, tamereren@gmail.com \\ ORCID: T. Eren (0000-0001-5282-3138), M. Hamurcu (0000-0002-6166-3946)
}

\begin{abstract}
Özet
Bu çalışmada, akademik teșvik tabanlı yeni bir performans değerlendirme modeli önerilmiștir. Önerilen yeni modelde, akademik teșvik puanları temel alınarak çok kriterli karar verme yöntemleri kullanılmıștır. İlk olarak Analitik Hiyerarși Prosesi (AHP) ile akademik faaliyetler için ağırlıklandırma yapılmış ve sonra TOPSIS yöntemi ile devlet üniversitesine bağlı fakültelerin akademik performansları sıralanmıștır. Aynı zamanda çalıșmada bir fakültenin bölümleri ve fakültede yer alan akademik personelin performanslarının değerlendirilmesi de yapılmıştır. Önerilen yeni model, toplam akademik puan, ortalama akademik teşvik puanı ve akademik teşvikten yararlanan personel oranları ile yapılan sıralamalar ile karşılaștırılmıștır. Sonuçta önerilen yeni model uygulanmış, etkili ve tarafsız bir değerlendirme ile performans sıralamasına olanak sağladığı görülmüsștür. Çalışmanın sonucunda değerlendirmelere yer verilerek hem önerilen model hem de uygulanmakta olan akademik teşvik ödeneği hakkında önerilerde bulunulmuştur.
\end{abstract}

Anahtar Kelimeler: Akademik teşvik ödeneği, Performans değerlendirmesi, Çok kriterli karar verme

\section{A Proposal of Academic Incentive Based Performance Evaluation: An Application in The Higher Education Institution}

\begin{abstract}
In this study, a new performance evaluation model based on academic incentives was proposed. In the proposed new model, multicriteria decision making methods were used based on academic incentive scores. We first weighted the academic activities with the analytical hierarchy process (AHP) and then ranked the academic performances of the faculties with the TOPSIS method. At the same time, the evaluation of the performance of academic staff in the faculty and departments of a faculty has also been carried out. The proposed new model was compared with the rankings made by the total academic score, the average academic incentive score, and the proportion of the staff benefiting from the academic incentive. In the study, the proposed new model has been applied and it has been seen to enable performance ranking with effective and unbiased evaluation. As a result of the study, evaluations were given and suggestions were made about both the proposed model and the academic incentive allowance being applied.
\end{abstract}

Keywords: Academic incentive, Performance evaluation, Multicriteria decision making

\section{Gíriș}

Günümüz küresel rekabet dünyasında, yükseköğretim kurumlarında kaliteli hizmet sunmak başarı için bir anahtardır. Yükseköğretim kurumları öğrencilerine kaliteli eğitim vermenin ve bilim dünyasında saygın bir yere sahip olmanın yollarına odaklanmaktadır. Aynı zamanda, ülkelerin ekonomik büyümesinde ve ulusun geleceğini şekillendirmede hayati bir rol oynamaktadır. Ayrıca bir ülkenin üstünlüğü, doğal kaynakları ve mevcut sanayi ka-

*Yazışma Adresi / Address for Correspondence:

Tamer Eren, Email: tamereren@gmail.com

Geliş Tarihi / Received Date: 24.07.2019

Kabul Tarihi / Accepted Date: 20.08.2019

Doi: 10.26701/uad.596163 pasitesinden ziyade yükseköğretim sistem dinamizmine bağlıdır (King, 1995). Günümüzde eğitim kurumları, bilgi teknolojisinin hızlı büyümesi, küreselleşme ve kaynak kısıtlamaları gibi zorluklar yaşamaktadır (Aly vd., 2014). Tüm bu zorlukların üstesinden gelmek amaciyla yükseköğretimin tüm süreçlerinde, mevcut durumlar yeniden ele alınarak ve kurum hedefleri güncellenerek düzenlemeler yapılmaktadır. Yükseköğretimin iyileștirilmesi ve kurum hedeflerine ulaşılması noktasında yapılabilecek faaliyetlerin kontrol atında tutulması ve izlenmesi büyük önem arz etmektedir. Bu noktada yükseköğretim kurumları olan üniversitelerin, üniversitelerde fakülte ve bölümlerin performanslarının izlenmesi ve değerlendirilmesi ön plana çıkmaktadır. Ülkenin bilim üreten ve katma değer oluşturan bir kurumu olmak amacıyla eği- 
tim-öğretim kabiliyetini artırmak için kısa-orta ve uzun vadeli hedefleriyle tüm bu birimlerin temelini oluşturan akademik personeli motive edecek faaliyetlere yer vererek performans artışının sağlanması önemli bir hal almaktadir.

Hızla değișen ve gelișen bilim dünyası karşısında uluslararası konumunu güçlendirmeyi hedefleyen Türkiye üniversiteleri, akademik performansını artırarak uluslararası alanda yerini yükseltmeyi hedeflemektedir. Bunun için çeşitli faaliyetler ile akademik personeli desteklemektedir. $\mathrm{Bu}$ desteklerden biri de 2015 yllından beri uygulanmakta olan akademik teşvik ödeneği sistemidir. Akademisyenlerin faaliyetlerini çeşitlendirme ve performanslarını arttırmaya yönelik olan bu destek ile hem bireysel hem de kurumsal performansın arttırılması sağlanmaya çalışılmaktadır. Üniversitelerde ve akademik camia içinde, iyi yetişmiş, kaliteli ve bilinçli bilim insanlarının önemi yadsınamaz. Üniversitelerin görevleri arasında yer alan araştırma ve nitelikli yayın yapma, eğitim-öğretim sunma için iyi yetişmiş kaliteli öğretim elemanlarının atanmasının gerekliliği kalitenin artırılması için elzemdir. Bununla birlikte kendini geliştiren ve daima yeniklere açı ve istekli akademisyenlerin olması ve yeterli maddi ve manevi imkânların sağlanması gibi nedenlerle, üniversitelerdeki akademik personelin çeşitli yönleri ve özellikleri ile performansının yönetilmesi gerekmektedir.

Bilimsel ilerleme ve bilginin geliştirilmesi ile birlikte gelecek nesillere aktarılmasının sağlanması üniversitelerin başlıca amacıdır (Kaptanoğlu ve Özok, 2006). Aynı zamanda üniversiteler, öğrenci odaklı bir yaklaşımla akademik faaliyetler ile üniversiteler arasında iyi bir konum amaçlamaktadır. Yükseköğretimde ulaşılması beklenen temel hedeflerin başında akademik etkinliği ile öğrenci beklentilerinin karşılanması gelmektedir. Bunu gerçekleştirmek için üniversitelerin performanslarının değerlendirilmesinde temel faktörlerden biri olan akademisyenlerin performansları olduğudur (Todorovic vd, 2011). Performans değerlendirme veya ölçümü için çeşitli alanlarda çok değişik uygulamalar şimdiye kadar yapılmıştır. $\mathrm{Bu}$ alanda yapılan çalışmalara bölüm 3 de yer verilmiştir. Ancak akademik performansın değerlendirilmesi, fiziksel çıtının bilimsel yayın olması ve çeşitlilik arz etmesi nedeniyle oldukça güçtür. Fakülte bazında akademik faaliyetlerin farklılaşması homojenliği bozmakta ve aynı çatı altında değerlendirme imkanını ortadan kaldırmaktadır.

Akademik teşvik ödeneğini, akademik personelin bir yl içinde yapmış olduğu akademik faaliyetlerin puanlandırılması sonucunda belirlenen toplam puanı oranında sağlanan teşvik olarak tanımlamak mümkündür. Sağlanan bu ödenek ile bireysel performansın yanı sıra bölüm, ilgili fakülte ve üniversite için de ölçülebilecek/değerlendirilmeye imkân sağlayabilecek bir puanlama süreci ortaya koymaktadır. Ancak tarafsız ve etkili bir değerlendirme modelinin ortaya tam anlamıla konulamaması bu alanda daha da çalışılması gerekliliğini ortaya koymaktadır. Aynı zamanda üniversiteler arasında farklılık gösteren atama kriterleri nedeni ile de temelde standart bir performans ölçüm veya değerlendirme siteminin olması gerekliliğini gözler önüne sermektedir. Belirli bir standardın olmaması nesnelliği ortadan kaldırmakta ve çeşitli problemlere de yol açabilmektedir. Bu bağlamda akademik teşvik ödeneği uygulaması, alınan akademik teşvik puanı doğrultusunda verilen ücret ile hangi akademik seviyede olursa olsun yayın yapmaya ve akademik faaliyetlerde bulunmayı teşvik ederken, ekstra bir motivasyon kaynağı ve aynı zamanda da akademik performansın değerlendirilmesi için çok iyi bir puanlama sistemi ortaya koymaktadır. Ancak fakülte bazında belirlenen akademik faaliyetler farklılaşmaktadır. Ayrıca puanlama sisteminde akademik faaliyet bazında belirli bir puan sınırı da söz konusudur.

Türkiye yükseköğretim sistemi için yeni bir uygulama olan akademik teşvik ödeneği sisteminin akademik camiada ne ölçüde kabul gördüğü, uygulamanın avantaj ve dezavantajlarının neler olduğu yapılan araştırma ve yayınlarda ortaya konulmuştur. Öncelikle yeni bir uygulama olan akademik teşvik ödeneği sürecinin devamlılığ ve geliştirilmesinde, bu teşvikten yararlanacak olan akademisyenlerin görüşleri önemlidir. Turhan ve Erol (2017), 2015 yılından itibaren ödenmeye başlanan akademik teşvik ödeneği için 50 akademik personelin görüşüne başvurarak incelemelerde bulunmuşlardır. Akademik teşvik ödeneği sisteminin akademisyenleri bilimsel çalışmaya yönelttiği, üreten akademisyenin ödüllendirdiği ve motive ettiği, akademisyenleri maddi olarak desteklediği, akademik yayınların sayısını arttırdığı ve akademisyenlerin yayınlarında çeşitlilik sağladığı için yararlı bulunulmuştur. Fakat, bu uygulamanın akademik çalışmaların niteliğinde düşmelere sebep olabileceğine ve etik açıdan sıkıntılar yaşanabileceğine dikkat çekerek, öz eleştirilerde bulunmuşlardır.

Akademik teşvik tutumunun, öğretim elemanlarının iş tatminini olumlu yönde etkilediği ve akademisyenlerin işlerinden motivasyonu için faaliyetleri ile bağlantılı olarak destek alması gerekliliği ile sağlanan desteğin motivasyon ve iş tatmini ile akademisyenlerin daha fazla üretken olacakları öngörülebilir (Alparslan, 2014). Aynı zamanda akademisyenlerin yapmış oldukları faaliyetler ile iş tatmininin sağlanması ve iş memnuniyeti, bilimsel ve teknik açıdan ilerlemenin sağlanması bakımından önemlidir (Murat ve Çevik, 2008). Akademisyenlerin teşvik sistemleri ile bireysel performanslarının arttırılmaya çalışılması aynı zamanda birim bazında performansı ve akabinde kurumsal olarak üniversitenin bilimsel performansına da katkı sağlayarak arttıracaktır. Üniversitelerin akademik performansları, marka değerleri ve uluslararası görünürlüklerini pozitif etkilemektedir. Yükseköğretim kurumlarının marka değerinin belirlenmesinin kriterlerinden birisi de bilime ve sanata katkıy ifade eden akademik performanstır (Erarslan, 2015). Bu konuda çeşitli değerlendirme süreçleri var olmuştur. Akademik Teşvik Ödeneği Yönetmeliği ile akademik performansın değerlendirilmesi 
standart bir hal almıștır. Yükseköğretimde kalitenin objektif olarak değerlendirilmesi ve geliştirilmesi için akademik performansın doğru bir biçimde değerlendirilmesi gerekir. Bu durumda ortaya konan akademik teşvik ödeneğinin akademisyenlerce değerlendirilip geliştirilme ve eksikliklerinin giderilmesi ile yapılacak çalışmalara ve getirilecek yeni düzenlemelere ışık tutacağı düşünülmektedir. Akademik teşvik ödeneği uygulaması üzerinden yapılan eleştiriler ve kaygılarda mevcuttur. Özellikle maddi kaygılar sonucunda ortaya çıkabilecek niteliksiz yayın sayısındaki artış ve etik problemler. Dolayısıyla bu durum yayın sayının artışını olumsuz etkileyecek ve performans değerlendirmelerinde doğru sonuçlar vermeyecektir.

Akademik teşvik uygulamasının akademisyenler tarafindan genel olarak yararlı bulunduğu belirlenmiştir. Ancak bazı akademisyenler niceliksel yayın artışının niteliği olumsuz yönde etkileyeceği yönünde görüş bildirmişlerdir. Ayrıca, akademik teşvik uygulamasının etik problemlere yol açabileceği ve maddi kaygıların bilimsel kaygılardan daha ön planda olmasına sebep olabileceğini ifade etmişlerdir. Akademik teşvik uygulamasının puanlama sisteminde problemlerin olduğunu ve puanlamada adalet konusunda sıkıntılar bulunduğu dile getirilmektedir (Okumuş ve Yurdakal, 2017). Tüm bu çalışmalar göstermektedir ki; akademik teşvik ödeneği sisteminin akademisyenleri motive ederek, performansın arttırılabileceği ve aynı zamanda bu sistemin daha da geliştirilmesi ve ortaya çıkabilecek olumsuzluklar için önlem alınması gerekmektedir.

Akademisyenler için akademik faaliyetlerin çeşitli kriter ve faktörler ile puanlandırma neticesinde ortaya çıkan değeri performansını oluşturmaktadır. Son yıllarda akademik teşvik ödeneği ile performans arttırılmaya çalışılmakta ve akademik teşvik ödeneğinde belirlenen kriterler ve yönetmelik çerçevesinde toplanan puanlar, akademisyenlerin akademik performanslarının ölçülmesinde kullanılmaktadır. Akademik performans değerlendirmesi, çeşitli süreçlerde de kullanılmaktadır. Çeşitli performans ölçüm veya değerlendirme süreçleri olmasına rağmen performansın değerlendirilmesi için; kolay, verileri aynı bazda değerlendirebilen, esnek, sözel olarak ifade edilen ölçütleri sayısallaştırabilen bir modelin olmaması ve akademik performans değerlendirme problemi içerdiği belirsizlik ve öznel değerlendirilebilen ölçütleri nedeni ile bulanık yöntemler kullanılmıştır (Kaptanoğlu ve Özok, 2006). Bu durumlar, iyi bir denetleme mekanizması ile aşılabileceği gibi değerlendirme süreçlerinde akademik teşvik tabanlı bir performans değerlendirme sisteminin gerekliliğini de ortaya koymaktadır. Akademik teşvik sistemi ile bir puanlama ortaya konulmaktadir. Ve bu puanlama neticesinde belirli kısıt altında puan hesaplanmaktadır. Ancak nitelik ve akademik faaliyet çeşitliliği ve bu faaliyetlerin birbirine göre önem seviyelerinin varlığı akademik teşvik puanını tabanda barındıracak yeni performans ölçüm süreçlerini gerekli kılmaktadır.
Çok Kriterli Karar Verme (ÇKKV), belirlenen değerlendirme kriterleri çizgisinde yine belirlenen alternatifler arasından çoklu karşılaştırmalar neticesinde belirli bir ağırlık, derece veya sıralama veren karar süreçleridir. Performans değerlendirme süreçlerinde de sıklıkla kullanılan bu yöntemlerin önde gelenleri: AHP, ANP, TOPSIS, VIKOR, PROMETHEE, ELECTRE'dir (Ağaç ve Birdoğan, 2016).

$\mathrm{Bu}$ çalışmada, akademik personelin yıl boyunca yaptığ çalışmalar neticesinde hesaplanan akademik teşvik puanları temel alınarak ÇKKV yöntemleri ile önce fakültelerin performanslarının sıralanması yapılmıștır. Daha sonra bir fakülte için bölümlerin ve daha sonra fakültedeki akademik unvanları bazında çeşitli sıralamalar ile performans ölçümleri/sıralamaları yapılmıştır. Fakülte bazında önem seviyeleri farklılaşan akademik faaliyetler için belirlenen 4 kriter doğrultusunda akademik faaliyetler AHP ile ağırlıklandırılmıştır. Ağırlıklandırma sonucunda ortaya çıkan değerler TOPSIS başlangıç matrisini oluşturmuştur. TOPSIS neticesinde fakültelerin performans sıralamaları yapılmıştır.

Akademik teşvik yönetmeliği bilim insanlarının çalışmalarını desteklemek ve onları güdülemek amacıyla ortaya çıkmıştır. Buna karşın, akademik teşvik sisteminin bilim insanlarını olumsuz yönde etkilediğine dair görüşler de mevcuttur. Esen (2016), çalışmasında, yönetmelikte akademik teşvik puanlarının toplanabileceği dokuz farklı kategorinin tüm akademisyenleri kapsadığından; ancak 'sergi', 'tasarım' ve 'patent' gibi başlıkların tüm akademisyenleri kapsamaktan uzak olduğundan bahsetmiştir. Bu konuda, Balcı (2015) patent, sergi ve tasarım gibi kategorilerin sosyal bilim alanında çalışan akademisyenlere göre olmadığını; en çok kullanılan kategorilerin ise "Yayın", "Atıf" ve "Tebliğ" kategorileri olduğunu ifade etmiştir.

$\mathrm{Bu}$ çalışma ile akademik teşvik puanı temelinde çok kriterli karar verme yöntemleri kullanılarak ortaya konulan yeni bir performans değerlendirme/sıralaması önerisinde bulunulmaktadır. Literatürde akademik teşvik puanı temelinde bir performans değerlendirme çalışması bulunmamaktadır. Literatüre katkı sağlayacak olan bu çalışma ile performans değerlendirmede yüksek öğretimde tarafsız ve bütüncül bir değerlendirme imkânı sunacaktır. Bu uygulama hem üniversiteler hem fakülteler hem bölüm ve akademik personellerin performans değerlendirilmesinde kullanılabilecek bir model olarak geniş kapsamlı bir uygulama alanını içermektedir.

Çalışmanın akışı şu şekildedir: İkinci bölümde literatür araştırmasına yer verilmiştir. Üçüncü bölümünde performans değerlendirmesi ve bu alanda yapılan literatür araştırmasına, dördüncü bölümde akademik teşvik ödeneği uygulamasına, beşinci bölümde AHP ve TOPSIS süreçlerine, altıncı bölümde detaylı uygulamaya ve son bölüm olan yedinci bölümde sonuç ve önerilere yer verilmiștir. 


\section{LITERATÜR ARAŞTIRMASI}

Akademik teşvik ödeneği uygulaması ile birlikte, akademik açıdan bu alanda yapılan yayın sayısı da yavaş yavaş artmaktadır. Genel değerlendirme niteliği taşıyan bu çalışmalarda uygulamanın önemli olduğu ve teşvik noktasında motive edici bir sistem olduğu görüşünde uzlaşılmaktadır. Yapılan bu çalışma da bir adım daha ileriye gidilerek akademik teşvik puanları temelinde bir performans ölçüm modeli ortaya koymaktadır. Şahin (2017), akademik teşvik ödeneği uygulamasının olası etkileri üzerine öğretim elemanlarının görüşleri doğrultusunda motivasyon kuramları bağlamında bir değerlendirme yaparak, uygulamasının kapsam-içerik kuramları açısından daha olumlu olduğu düşünülen uygulamalara sahipken, süreç kuramları ve güncel kuramlar açısından amaca ulaşmada etkisinin az olduğu sonucuna ulaşılmıştır. Küçük ve Karabacak (2017), 2015 yılı akademik teşvik uygulaması üzerine değerlendirmelerini ortaya koymuşlar ve çalışmanın sonucunda ortaya çıkan en önemli bulgunun, farklı alanlarda çalışan katılımcı bilim insanlarının tamamının, uygulamanın kuramsal amacına ulaşabilmesi ve sağlanan ödeneğin karşılığının topluma ve ülkeye hizmet edebilmesi için teşvik mevzuatının var olan eksikliklerinin telafi edilerek devam etmesi noktasında olmuştur.

Çürüksulu (2015), çalışmasında performans yönetimi ve yükseköğretim sisteminin kavramsal çerçevesini çizmiştir. Türkiye'deki ve dünyadaki üniversite sistemlerinin gelişiminin tarihsel bağlamda ele alınmasının ardından akademik performansın ölçümü dünya üniversiteleri sıralama sistemleri açısından çalışmada incelenmiştir. Özellikle temel performans kriterleri, uluslararası kapsamda taranan endeksler, akademik performansın ölçümündeki yasal düzenlemeler ve akademik veri yönetim sistemi araştırma konusu yapılarak Türkiye'den üç üniversitenin karşılaştırılmasıyla çalışma tamamlanmıştır.

Göksu ve Bolat (2017), toplam 107 devlet üniversitesinden 86'sına ait akademik teşvik komisyonu değerlendirme sonuçlarıyla ilgili verileri kullanarak akademik teşvik uygulamasına ait ilk sonuçların betimsel analizini yapmış ve aynı zamanda çalışmaların mevcut durumunu ortaya koyarak bazı değişkenler açısından değerlendirmelerde bulunmuşlardır. Çalışmada elde edilen veriler bölgeler, üniversiteler, birimler, unvan, cinsiyet, minimum puan, maksimum puan ve teşvik alma oranı açısından incelenerek değerlendirilmiş ve akademik teşvik puanları, 20152016 URAP (University Ranking by Academic Performance) sıralamasıyla karşılaştırılmıştır.

Esen ve Esen (2015), yaptıkları çalışmada öğretim üyelerinin performans değerlendirme sistemine ilişkin tutumlarını çeşitli istatistiksel analizler ile ölçmüşlerdir. Araştırma sonunda elde edilen bulgulara göre, öğretim üyelerinin, kendi performans boyutları içinde en önemli olarak algıladıkları faktörler sırasıyla araştırma, eğitim-öğretim, topluma hizmet ve yönetime destektir. Ayrıca öğretim üyeleri, performanslarının belirli periyodlarla değerlendirilebileceği bir performans değerlendirme sistemlerine olumlu bakmaktadır. Ateș ve Akpınar (2017), kamu yönetimi alanında yer alan bölümlerindeki akademisyenlerin akademik performanslarını, üniversitelerin Akademik Teşvik Yönetmeliğine göre vermiş oldukları teşvikler ve Google Akademik Atıflar (Google Scholar Citations) listelerindeki verileri baz alarak bir değerlendirmenin mümkün olduğundan bahsederek Türkiye'deki kamu yönetimi alanında çalışanların durumunu ortaya koymaktadirlar.

Yüksel (2015), çalışmasında eğitim faaliyetinin doğası gereği çok faktörlü bir yapıya sahip olması ile eğitim sisteminin performansını değerlendirmeye yönelik bir algoritma önermiştir. Performans değerlendirme algoritmasını eğitim olgusunun temel karakteristiklerini dikkate alan bir yaklaşımla yapılandırmıştır. Bir sistemin performansının biliniyor olması karar verme de ve dolayısıyla eğitim yöneticileri açısından önemlidir. Ayrıca yazar gelecek zaman diliminde ve koşullarında eğitim sisteminin performansının öngörülmesinin, stratejik kararlar ve planlama açısından önemli olacağını söylemiştir. Yükseköğretim sistemlerinin, günün değişen koşullarına uyum sağlayabilmesi için akademisyenlerin öğretim performanslarının değerlendirme süreçlerine tabi tutulması ile gelişme sağlanabileceği açıktır (Kalaycı, 2009). Ortaya konulabilecek performans ölçütleri değerlendirme ve sıralama noktalarında önemli rol oynayarak performans ölçümünün veya değerlendirmesinin temelini oluşturmaktadır.

Genel anlamda üniversitelerin performanslarının geliştirilmesi ve yeniden gözden geçirilmesi gerekliliği üzerinde durulmasının (Siew, 2015, Yu-Jen Tsen, 2013, Kaur ve Bhalla, 2009) yanı sıra Çin Halk Cumhuriyeti, Kuzey Kore ve İngiltere gibi ülkelerde hükümet ve akademik kurum yöneticileri, üniversiteleri dünya standartlarına yükseltmek ve ülkelerini kalitenin odağı haline getirmek için özel çalışmalar yürütmektedirler (Chen vd., 2006).

Simmons (2002), performans değerlendirme sisteminin kabul edilmesinin sistemin tasarımına akademik personelin katılmasıyla mümkün olacağını belirtirken performans değerlendirmenin yönetimsel kararlarla sonuçlanması yerine akademide içsel motivasyon, öz-disiplin ve çabanın önemine değinmiş ve baskı olmadan değerlendirmenin kişiye özgü yapılması önerilmiştir. Ayrıca çalışması sonucunda terfi, ücretlendirme gibi kararların alınması uygun bulunmazken, sistemin asıl olarak iyileştirme üzerine odaklanması gerektiğine vurgu yapılmıştır

Taylor (2001) çalışmasında akademisyenlerin araştırma ve hibe yardımları ve yayınlar üzerinde odaklanıp niceliği en üst düzeye çıkarmaya yönelip çabalarını arttırmaya yönelik çalışmalarının artmaya başladığından bahsederek bazı araştırmacıların niteliğinde düşüş yaşadığını belirtmiştir.

Yokuş vd. (2017), çalışmalarında akademik teşvik sistemi hakkındaki akademisyen görüşlerini belirlemeyi amaç- 
layarak, farklı üniversitelerde görev yapan 27 akademisyenden oluşan grup ile yaptıkları çalışmanın sonucunda, akademik camianın nitelikli çalışma yapamadığını, bu sistemin akademik üretkenliği artırmayı amaçladığını, fakat etik ihlallere yol açtığı için bazı akademisyenleri isteksiz kıldığını belirtmişlerdir. Doğan (2017), çalışmasında akademik performans odaklı dokuz uluslararası üniversite sıralama sistemini ele almıştır. Yapılan bu çalışmanın sonucunda bir üniversitenin sıralamalardaki konumunun kalitesi ile eşdeğer tutulamayacağı anlaşılmıştır ve sıralamalarının neyi, nasıl ölçtüğü bilinmeden önemli kararları verme amacıyla kullanılmaması gerekliliği sonucuna varmıştır.

Mahdi (2011), gelişen ve ilerleyen eğitim alanı ile eğitim kurumları hizmet kalitesini artırmak ve performanslarını ölçmek için girişimde bulunmaktadır. Performans değerlendirme de birden çok faktörün etki etmesi, çok yönlü değerlendirilmesini gerekli kılmaktadır. Çalışmasında çok ölçütlü karar verme yöntemlerinden TOPSIS ile birlikte bulanık Delphi kullanılarak, Gazi Üniversitesi Mühendislik Fakültesinde bulunan bölümleri, akademik performans açısından karşılaştırmıştır.

Çeşitli üniversite tanılarının yanında revaçta olan girişimci üniversite kavramını aktif, rekabetçi, kaliteli, iş çevreleriyle etkili iletişim içinde, piyasa odaklı, yetenekli ögrencilerinin yanında deneyimli ve kaliteli akademik personele sahip, sosyo-ekonomik çevresinin gereksinimlerine cevap verebilen, öğrenci ve akademik personeli ile araştırma fonlarını çekebilen, kendine yeten üniversiteler olarak tanımlanmıştır (Mautner, 2005).

Eğitim kurumları verdikleri hizmet kalitesini eğitim alanındaki gelişmeleri takip edebilmek ve rekabet gücünü sürdürebilmek amacıyla hizmet kalitesin yükseltmek ve performanslarını ölçmek için çeşitli metotların uygulandığı görülmektedir. Performans ölçümüne ise birden fazla faktör etki ettiğinden bahseden Torohay, çok ölçütlü karar verme yöntemlerinden TOPSIS kullanılarak, Gazi Üniversitesi Mühendislik Fakültesinde bulunan bölümleri akademik performans açısından karşılaştırmıştır. (Torohay, 2015). Aynı zamanda, araştırmacıların akademik üretkenliklerinin hangi faktörlere göre farklılaştığının belirlenmesi üzerine yapılan analizlere göre akademisyenlerin akademik üretkenlikleri temelde unvana göre değişmekle birlikte, yardımcı doçent ve doçentlerin başka üniversitelerde de ders vermelerinin üretkenliklerini düşürdügünü belirtmiştir. Araştırma görevlileri için öncelikli olarak yaş faktörü ardından ise çalıştıkları üniversitenin devlet veya vakıf üniversitesi olması etkili olmuştur. Öğretim görevlilerine bakıldığında ise cinsiyetin üretkenlik açısından ayırt edici bir faktör olduğu görülmüștür (Eti, 2017). Üniversitelerin performans ölçümünde ve sıralanmasında; üniversite fakültelerinin ve fakültelerde bölümlerin sıralanmasında da çeşitli yöntemler ve süreçler uygulanmaktadır. Örneğin; Akademisyen sayısı, öğrenci sayısı, öğrenci başına düşen akademisyen sayısı, yayın sa- yısı, lisansüstü öğrenci sayısı, yapılan tez sayısı gibi çeşitli ölçütler değerlendirilmektedir. Saka ve Yaman (2011), derleme niteliğinde olan çalışmalarında üniversiteler arasında yapılan sıralama sistemlerini tanıtarak çok çeşitli sistemlerin varlığından bahsetmişler ve bu sistemlerin her birinin farklı özellik ve değerlendirme kriterlerine sahip olduğundan bahsetmişlerdir. Ömürbek vd. (2014), çalışmalarında ÇKKV yöntemleri ile ADIM (Aydın, Denizli, Isparta, Muğla) üniversitelerinin performans değerlendirmesi yapılmışlardır. Çalışmada öncelikle ADIM üniversitelerinin performanslarının değerlendirilmesinde kullanılan kriterlerin belirlenmesinde ilgili literatür çalışmaları ve üniversitelerin faaliyet ve değerlendirme raporlarındaki bilgiler dikkate alınarak 21 kriter belirlenmiştir. Kriterlerin ağırlıkları AHP yöntemi ile belirlendikten sonra TOPSIS ve VIKOR yöntemleri uygulanmıştır. Her iki yöntemde de aynı üniversite ilk sırayı almıştır. Kutlar vd. (2004), fakültelerin Veri Zarflama Analizi (VZA) ile performans değerlendirmesi yaparak fakültelerin verimlilik skorlarını tespit etmişler ve değerlendirmelerde bulunulmuşlardır. Wu vd. (2012), üniversitelerin değerlendirmesinde profesyonellik ve yönetim ana başlıklarında çeşitli faktörler kullanılarak sıralama yapmışlardır. Koç vd. (2010), dünyadaki üniversiteleri sıralayan kuruluşların ölçütlerini dikkate almışlardır. Performansın artırılmasına yönelik etkenleri, Web performansı ve akademik performans açısından ayırarak, web performansı açısından, katılımcılar tarafından en sık vurgulanan konular arasında, öğretim elemanlarının kişisel web sayfalarının oluşturulması, ders notları, ders programları ve yayın özetlerinin online yayınlaması, mevcut bilimsel araştırmaların, projelerin ve laboratuvarların tanıtımlarının arttırılması, özel sektörle iş birliği yapılması yer almıştır. Makale sayılarının arttırılması, kaliteli yayınların oluşturulması, deneysel çalışmaların arttırılması, deneylerin yapılacağı laboratuvarların akredite edilmesi, deneylerde çalışacak araştırma görevlilerinin, yüksek lisans ve doktora öğrencilerinin arttırılması faktörleri akademik performansın arttırılması için sıkça vurgulanan öneriler olmuştur. Tüm bu çalışmalar konunun önemini ortaya koymakta ve performans değerlendirme süreçlerinin yükseköğretim kurumlarının gelişmesinde önemli bir gösterge olduğunu gözler önüne sermektedir.

\section{PERFORMANS DEĞERLENDIRMESI}

Performans yönetiminin temel amacı, performansa ilişkin kriterlerin belirlenmesi, performansın izlenmesi, ölçülmesi, değerlendirilmesi ve tarafların bilgilendirilmesi yoluyla performansın geliştirilmesini içermektedir. Yönetim biliminde performans, birey bazında ve örgüt bazında olmak üzere iki boyutta ele alınmakta olup; bir kurumda çalışanların başarı ölçümünü ilgilendirirken, birey bazında performans yönetimi; örgütün yerine getirdiği faaliyetlerin, ürettiği mal ve hizmetlerin tutumluluk, verimlilik ve etkinlik, kalite ve kamu örgütlerinde bu sayılanlara ek olarak hakkaniyet ölçütlerine göre sunulmasını 
ise örgüt bazında performansı kapsamaktadır. Performans kriterlerinin belirlenmesi ile başlayan performans yönetim süreci, performansın izlenmesi, performansın değerlendirilmesi, performansın geliştirilmesi süreçlerini kapsamaktadır (Çeliksoy 2009). Performans ölçümü bireysel performansın ölçümü olabileceği gibi bir birim, ünite ve kurumun performansının ölçümü de olabilir. Performans ölçümü, performans değerlendirme, etkinliğin ölçümü gibi farklı başlıklar altında yer alabilen değerlendirme sürecinde çeşitli yöntemler kullanılmıştır. Tablo 1'de literatürde yer alan çeşitli çalışmalar gösterilmektedir. Delphi, AHP, TOPSIS, Dengeli Skor Kart, Veri Zarflama Analizi, ANP, SERVQUAL ve bu yöntemlerin bulanık değerlendirmeleri gibi çok çeşitli yöntemler ayrı ayrı veya birlikte uygulamaları vardır.

Tablo 1. Yüksek Öğrenimde performans ölçümünde çeşitli uygulamalar

\begin{tabular}{|l|l|l|l|l|}
\hline Nu. & Yazar/Yazarlar & Yıl & $\begin{array}{c}\text { Kullanılan } \\
\text { Yöntem }\end{array}$ & \multicolumn{1}{|c|}{ Amaç } \\
\hline 1 & $\begin{array}{l}\text { Torağay ve } \\
\text { Arıkan }\end{array}$ & 2015 & Delphi-TOPSIS & Performans değerlendirme \\
\hline 2 & Samut & 2014 & AHP-TOPSIS & Performans değerlendirme \\
\hline 3 & Qiang & 2014 & Bulanık AHP & Performans değerlendirme \\
\hline 4 & Uzgören ve Şahin & 2013 & VZA & Performans ölçümü \\
\hline 5 & Lupo & 2013 & $\begin{array}{l}\text { Bulanık SER- } \\
\text { VQUAL }\end{array}$ & Eğitim kalitesinin ölçümü \\
\hline 6 & Wu vd. & 2012 & AHP-VIKOR & Performans değerlendirme \\
\hline 7 & Soba & 2012 & AHP & Performans değerlendirme \\
\hline 8 & $\begin{array}{l}\text { Hayrapetyan ve } \\
\text { Kuruvila }\end{array}$ & 2011 & $\begin{array}{l}\text { AHP-Denge- } \\
\text { lenmiş Skor } \\
\text { Kart }\end{array}$ & Fakültenin değerlendirilmesi \\
\hline 9 & Lee & 2010 & Bulanık AHP & Performans değerlendirme \\
\hline 10 & Azma & 2010 & $\begin{array}{l}\text { Dengeli Skor } \\
\text { Kart }\end{array}$ & Performans değerlendirme \\
\hline 11 & $\begin{array}{l}\text { Umayal Karpa- } \\
\text { gam ve Suganthi }\end{array}$ & 2010 & $\begin{array}{l}\text { AHP-Dengeli } \\
\text { Skor Kart }\end{array}$ & Performans ölçümü \\
\hline 12 & Lee vd. & 2010 & Bulanık AHP & Performans değerlendirme \\
\hline 13 & Rouyendegh vd & 2009 & VZA-ANP & Performans değerlendirme \\
\hline 14 & Özden & 2008 & VZA & Etkinliğin ölçülmesi \\
\hline 15 & Babacan vd. & 2007 & VZA & Etkinliğin ölçülmesi \\
\hline 16 & $\begin{array}{l}\text { Kaptanoğlu ve } \\
\text { Özok }\end{array}$ & 2006 & Bulanık AHP & Performans değerlendirme \\
\hline 17 & Hsieh vd. & 2006 & Delphi & Performans ölçümü \\
\hline 18 & Grandzol & 2005 & AHP & Fakültenin değerlendirilmesi \\
\hline 19 & Badri ve Abdulla & 2004 & AHP & Fakültenin değerlendirilmesi \\
\hline 20 & Bahurmoz & 2003 & Fakültenin değerlendirilmesi \\
\hline 21 & Lii vd. & AHPltenin değerlendirilmesi \\
\hline
\end{tabular}

\section{AKADEMIK TEŞVIK ÖDENEĞi UYGULAMASI}

Akademik teşvik ödeneği, akademik faaliyetleri arttırmak ve bilim insanlarını maddi yönden motive etmek amacıyla uygulanmakta olan bir destektir. Aynı zamanda gelişen ve hızla ilerleyen bilim toplumun ayak uydurmak ve bilimsel üretkenliği arttırmak düşüncesiyle akademisyenleri teşvik etmek amaçları gütmektedir. Dokuz ana başlık altında puanlama sistemi olarak ortaya konan teşvik sistemi proje, araştırma, yayın, tasarım, patent, atıf, tebliğ ve ödül olarak çeşitlenmektedir. Tablo 2'de bu dokuz başl1ğın akademik teşvik ödeneğinde belirtilen tanımları yer almaktadır. Belirlenen her bir akademik faaliyet 30 puanı aşmamak ve toplam puan 100 olacak şekilde yapılan puanlama ile akademik teşvik puanı hesaplanır ve bu puan neticesinde puan orana göre aylık yıl boyunca akademik personele ödeme yapılır (Akademik teşvik ödeneği yönetmeliği, 2017).

\begin{tabular}{|c|c|c|}
\hline $\begin{array}{l}\mathrm{Nu}- \\
\text { mara }\end{array}$ & $\begin{array}{l}\text { Faaliyet } \\
\text { Türü }\end{array}$ & Açıklama \\
\hline 1 & Proje & $\begin{array}{l}\text { Konusu, amacı, kapsamı, süresi, özel şartları ve bütçesi } \\
\text { belirlenmiş; yeni bilgiler üretilmesi ve bilimsel yorum- } \\
\text { larının yapılması veya teknolojik/sosyal problemlerin } \\
\text { çözümlenmesi için bilimsel esaslara uygun olarak } \\
\text { gerçekleştirilen ve sonuç raporu ilgili kurumlarca kabul } \\
\text { edilmiş çalışmaları, }\end{array}$ \\
\hline 2 & Araştırma & $\begin{array}{l}\text { Öğretim elemanının çalıştığı kurum tarafından ve } \\
\text { araştırmanın ilgili olduğu kurumlarca önceden onaylı, } \\
\text { başlangıcı belgelenmiş, çalışmanın sonuç raporu aynı } \\
\text { kurumlarca tescillenmiş, herhangi bir proje kapsamında } \\
\text { yürütülmemiş, en az üç ay süreyle yapılmış eski bilgileri } \\
\text { test etmeye, bir problemi çözmeye veya analiz etmeye, } \\
\text { bir teoriyi geliştirmeye, yeni bir teori ortaya koymaya, } \\
\text { yeni bilgi, uygulama, teknoloji veya yaratıcı eser } \\
\text { üretmeye yönelik, süreçleri raporlaştırılmış, Yükseköğ- } \\
\text { retim Kurulu ve yükseköğretim kurumları tarafından } \\
\text { yürütülen değişim programlarının teşvik kapsamı dışın- } \\
\text { da kalan ve bu Yönetmelikteki diğer faaliyet türlerine } \\
\text { girmeyen sistematik çalışmaları, }\end{array}$ \\
\hline 3 & Yayın & $\begin{array}{l}\text { Tez çalışmaları hariç, araştırma kitabı, ders kitabı, kitap } \\
\text { bölümü, ansiklopedi konusu ve makale yazarlıkları ile } \\
\text { editörlük, editörler kurulu üyeliği, tercüme ve tercüme } \\
\text { editörlüklerini, }\end{array}$ \\
\hline 4 & Tasarım & $\begin{array}{l}\text { Bir sanat eserinin, yapının veya teknik ürünün ilk taslağı, } \\
\text { çizim ve dizayn halini, }\end{array}$ \\
\hline 5 & Sergi & $\begin{array}{l}\text { Öğretim elemanının akademik faaliyet alanı ile akade- } \\
\text { mik ve bilimsel niteliği haiz işitsel ve görsel etkinliklere } \\
\text { dair tüm sergi, bienal, gösteri, dinleti, konser, festival ve } \\
\text { gösterim etkinliklerini, }\end{array}$ \\
\hline 6 & Patent & $\begin{array}{l}\text { Ulusal ve uluslararası kurumlar tarafından tescillenmiş } \\
\text { patentleri, }\end{array}$ \\
\hline 7 & Atıf & $\begin{array}{l}\text { Öğretim elemanının yazar olarak yer almadığı yayınlar- } \\
\text { da öğretim elemanının eserlerine yapılan atıfları, }\end{array}$ \\
\hline 8 & Tebliğ & $\begin{array}{l}\text { Bilim kurulu bulunan uluslararası düzeydeki toplantı- } \\
\text { larda sunulmuş ve yayımlanmış (bildiri kitabı, özetler } \\
\text { kitabı, web sitesi veya CD, DVD gibi medya ortamında) } \\
\text { tebliğleri }\end{array}$ \\
\hline 9 & Ödül & $\begin{array}{l}\text { Öğretim elemanının, kadrosunun bulunduğu kurum } \\
\text { tarafından verilenler hariç olmak üzere akademik faali- } \\
\text { yet alanında gerçekleştirdiği faaliyetlere karşılık olarak } \\
\text { verilmiş akademik ve sanatsal ödülleri }\end{array}$ \\
\hline
\end{tabular}

Proje, ulusal veya uluslararası destekli sonuçlandırılmış projeler olan dünya bankası, Avrupa birliği ve Avrupa konseyi destekli proje, diğer resmi kurum ve kuruluşlar tarafından desteklenen proje, TUBA ve TÜBİTAK destekli proje, kalkınma destekli proje Sanayi tezleri programı (SAN-TEZ) projesi, diğer kamu kuruluşları ve yüksek öğretim kurumları tarafından desteklenen bilimsel araştırma projesi ve özel kuruluşlar başlıkları altında yer alan faaliyetlerdir. Araştırma, yurt içi ve yurt dışı akademik araştırmalarını kapsamaktadır. Yayın, araştırma kitabı, ders kitabı, kitapta editörlük, kitap bölümü, kitap tercümesi, kitap tercümesinde editörlük, ansiklopedi konu/ madde yazarı, dergi editörlüğü, kitap/dergi editörler kurulu üyeliği, özgün makale, teknik not, yorum, vaka takdimi, editöre mektup, özet, kitap kritiği, araştırma notu, 
bilirkişi raporu ve benzeri faaliyetler ve ulusal veya uluslararası boyutta yayımlanmış ses ve /veya görüntü kaydı faaliyetlerini başlıkları altında puanlandırılmaktadır. Tasarım, sanat tasarım (bina, çevre, eser, yayın, mekân, obje) bilimsel tasarım, TSE/TPE tarafından tescillenmiş faydalı obje, özgün kişisel etkinlik karma etkinlikleri kapsamaktadır. Patent, alanında ulusal veya uluslararası tescillenmiş patentleri kapsamaktadır. Atıf, öğretim üyesi/elemanının yazar olarak yer almadığı uluslararası veya ulusal kitaplarda, öğretim üyesi/elemanının eserlerine yapılan her bir atıf, SSCI (Social Sciences Citation Index.), SCIExp (Science Citation Index-Expanded), AHCI (Art and Humanities Citation Index) indekslerindeki dergilerdeki ve bunlar dışındaki alan indekslerindeki dergiler ile diğer hakemli uluslararası ve ulusal dergilerdeki, öğretim üyesi/ elemanının yazar olarak yer almadığı makalelerde, öğretim üyesi/elemanının eserlerine yapılan her bir atıf için yapılan akademik faaliyetleri içerir. Tebliğ, Uluslararası kongre, sempozyum, panel, çalıştay gibi bilimsel, sanatsal toplantılarda sözlü olarak sunulan ve tam metin veya özet metin olarak yayımlanan veya poster olarak sunulan akademik çalışmaları kapsamaktadır. Ödül, TÜBA ve TÜBİTAK'tan alınan ödül, Alanında yurtiçi veya yurtdışı kamu kurum ve kuruluşlarından alınan ödül, Uluslararası BSE (Bilim ve sanat kurulu olan kongre, kurultay, sempozyum, konferans ve festival gibi etkinlikler.), Ulusal BSE ve Alanından özel kurum ve kuruluşlarından alınan ödül başlıkları altında puanlandırılmaktadır.

\section{5. ÇOK KRITERLI KARAR VERME}

Çok kriterli karar verme, karar verme problemlerinde kriter sayısının birden fazla olduğu durumlarda, çözüm bulabilmek amacıyla çeşitli bilimsel yöntemler ortaya konularak seçimin yapılmasıdır (Göksu, 2008). Çok kriterli karar verme geçmişte olduğu gibi günümüzde daha da yaygınlaşarak kullanılmaktadır. Karar verme süreçlerin etkili ve net sonuçlar ortaya koyan yöntemler karar vericiler için yardımcı olmaktadır. Özellikle AHP, ANP, TOPSIS, VIKOR ve PROMETHEE yöntemleri ayrı ayrı veya birbirleri ile entegre edilmiş halde uygulanabilmektedir (Zhou vd., 2006). Analitik süreçleri içeren bu yöntemler kolay ve karmaşık olmayan adımlar içermektedir. İleri bir matematik bilgisi gerektirmeyen bu karar verme süreçleri çok geniş alanda uygulanmaktadır.

AHP ile medya planlama (Alağaş vd., 2017), yüksek hızlı tren istasyon yeri seçimi (Eren vd., 2017), AHP ve TOPSIS yöntemi ile bütünleşik olarak kitap basımevi seçiminde (Geyik vd., 2016), monoray projelerinin seçiminde hedef program ᄀlama ile birlikte AHP (Gür vd., 2016a), konferans seçi $\neg$ minde ANP (Gür vd., 2016b), kamu kurumunda proje seçiminde ANP-HP (Gür vd., 2017), teknoloji seçiminde (Hamurcu ve Eren, 2017), yüksek hızlı tren projelerinin önceliklendirilmesinde AHP (Hamurcu ve Eren, 2016c), monoray araç seçiminde (Hamurcu ve Eren, 2016ç), gü $\neg$ zergah seçiminde (Hamurcu ve Eren, 2016d); raylı sistem projeleri kararında AHP-ANP-HP kombinasyonu (Haᄀmurcu ve Eren, 2017a) gibi çalışmalar literatürde yer almaktadır. Ayrıca, bilimsel dergi seçiminde ANP (Hamurcu ve Eren, 2017b), sürdürülebilir kentsel ulaşım için bulanık AHP-VIKOR (Hamurcu ve Eren, 2017c), ulaşım planlama kararlarında (Hamurcu ve Eren, 2017d), proje seçiminde AHP-HP (hamurcu vd., 2016; Hamurcu vd. 2017), monoray projeleri seçiminde (Taş vd., 2017a), hat tipinin belirlenmesinde AHP- Promethee (Taş vd., 2017b) ve stok kontrol süreçlerinde ANP (Beğik vd., 2017) kullanımı gibi çalışmalarda da analitik karar verme yöntemleri kullanılmıştır.

\subsection{AHP (Analitik Hiyerarşi Prosesi)}

Analitik Hiyerarşi Prosesi (AHP), 1977 yılında Thomas L. Saaty (1980) tarafindan geliştirilen geniş bir alanda kullanılan çok kriterli karar verme metotlarından biridir. AHP yöntemi, hiyerarşik yapının kurulması, ikili karşılaştırma matrisinin oluşturulması, göreli önem vektörünün (özvektörün) hesaplanması ve faktör kıyaslamalarındaki tutarlılığın hesaplanması adımlarından oluşmaktadır (Dinç vd., 2019; Dinç vd., 2018; Hamurcu ve Eren, 2018) Çalışmada AHP yöntemi sadece kriter ağırlıklandırmalarında kullanıldığı için, yöntemin alternatif karar noktaları için uygulanan adımlarına yer verilmemiştir. Şekil 1'de gösterilen hiyerarşi yapısı: en üstte problemin/karar sürecinin amac1, bir alt seviyede; değerlendirme kriterleri ve en altta önem seviyeleri bulunmak istenen alternatifler yer almaktadır (Dağdeviren vd., 2009). Bu çalışmada AHP ile TOPSIS yönteminde kullanılacak kriterlerin önem seviyelerini ve başlangıç matrisi değerleri bulunmaya çalışılmaktadır.

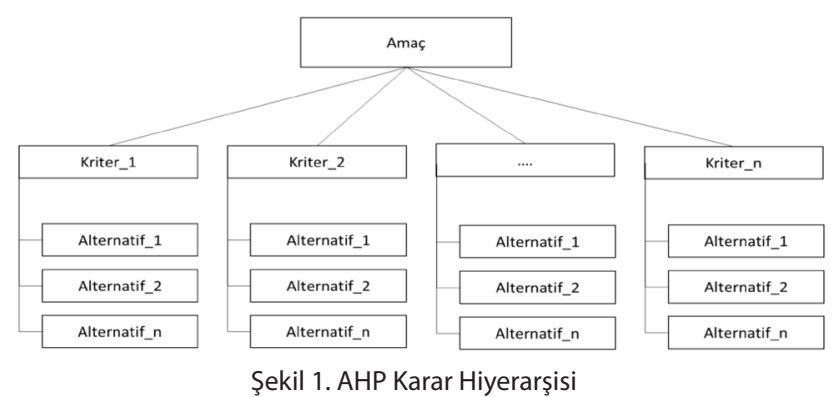

Karar probleminin belirlenmesi ve karar hiyerarşisinin oluşturulmasından sonra, AHP yönteminin genel adımları;

İkili karşılaştırma matrisi ve göreceli önem ağırlık değerlerinin bulunması $\mathrm{Bu}$ adımda, kriterlerin göreceli önem ağırlık değerleri verilmekte ve ikili karşılaştırma matrisi oluşturulmaktadır. Kriterlerin ikili karşılaştırma değerleri, karar vericilerin bilgi, deneyim ve uzmanlık veya anket çalışması ile elde edilen değerlendirmelere dayanmaktadir.

Kriterler ve her kriter doğrultusunda alt seviyede yer alan faktörlerin ayrı ayrı karşılaştırılması sürecin Saaty'nin 1-9 önem skalası kullanılmaktadır (Saaty, 2004). Tablo 3'te bu skala gösterilmektedir. 
Tablo 3. Önem Skalası

\begin{tabular}{|c|c|}
\hline Önem Değeri & Açıklama \\
\hline 1 & Eşit dereceli önemli \\
\hline 3 & Kısmen daha önemli \\
\hline 5 & Kuvvetle daha önemli \\
\hline 7 & Çok kuvvetle daha önemli \\
\hline 9 & Aşırı derecede daha önemli \\
\hline $2-4-6-8$ & Ara değerler \\
\hline
\end{tabular}

Özvektör değeri ve tutarlılık oranı: Krterler arası ve her kriter için alternatiflerin ikili karşılaştırma matrisindeki kriterlerin özvektör değeri bulunur ve bu değerlerin (wi) hesaplanmasında denklem (1) kullanılmaktadır.

$$
w_{i}=\frac{1}{n} * \sum_{j=1}^{n} \frac{a_{i j}}{\sum_{j=1}^{n} a_{i j}}
$$

Kriterlere ait özvektör değerini bulunduktan sonra; tutarlılık oranı, tutarlılık göstergesi ve özdeğer hesaplanmaktadır. Tutarlılık oranı (Consistency Rate; CR; TO), ikili karşılaştırma anında verilen değerlerin birbirleri arasındaki ilişkinin tutarlı olup olmadığını göstermektedir. Tutarlılık oranının 0,10'dan düşük olması gerekmektedir.Aksi durumda yapılan değerlendirme tekrar gözden geçirilir. Tutarlılık oranı, Denklem (2) kullanılarak hesaplanmaktadır

$$
C R=\frac{C I}{R I}
$$

Tutarlılık Göstergesi'nin (Consistency Index; CI; TG) hesaplanması Denklem (3) kullanılmaktadır.

$$
C I=\frac{\Lambda_{\max }-n}{n-1}
$$

Tutarlılık Göstergesi değerinin hesaplanabilmesi için; maksimum özdeğer'in ( $\lambda \max )$ Denklem (4) kullanılarak bulunması gerekmektedir.

$$
\kappa_{\max }=\frac{1}{n} \sum_{i=1}^{n} \frac{(a w)_{i}}{w}
$$

Denklem (2)'de yer alan Rastgele İndeks (Random Index-RI) değeri (rassallık göstergeleri) Tablo 4'te gösterilmektedir

Yapılan ikili karşılaştırmaların uygun olup olmadığının testinin de yapıldığı AHP sürecinde bu test için rassallık indeksi kullanılmaktadır. Yapılan tutarlılık oranının 0,10'den küçük olması yapılan karşılaştırma ve işlemlerin tutarlı ve uygun olduğu sonucuna varılmaktadır. Aynı zamanda yapılan işlemlerin doğruluğunun kontrolü de bu yolla sağlanabilmektedir.

Tablo 4. Rassallık indeksi

\begin{tabular}{|c|c|c|c|c|c|c|c|c|c|c|}
\hline $\mathrm{N}$ & 1 & 2 & 3 & 4 & 5 & 6 & 7 & 8 & 9 & 10 \\
\hline $\mathrm{RI}$ & 0 & 0 & 0.58 & 0.90 & 1.12 & 1.24 & 1.32 & 1.41 & 1.45 & 1.49 \\
\hline
\end{tabular}

Önem ağırlıklarının bulunması ve alternatiflerin sıralanması: Kriterler için yapılan bu işlemler, alternatiflerin değerlendirilmesi içinde aynısı uygulanmaktadır. Kriter önem ağırlıkları ile her kriter için bulunan alternatiflerin önem ağırlıklarının matris çarpımı sonucunda elde edilen karar alternatif puanları büyükten küçüğe doğru sıralanır ve birinci sıradaki alternatif en iyi alternatif olarak belirlenir. Ancak bu çalışmada sadece kriter ağırlıkları bulunmuştur.

\subsection{TOPSIS (Technique for Order Preference by Similarity to Ideal Solution)}

Bu yöntem ilk defa 1981 yılında Hwang ve Yoon tarafından ortaya konulmuş ve daha sonra 1992 yılında Chen ve Hwang (1992), tarafından yöntem geliştirilmiştir. Yöntemi amacı seçilen alternatifin ideal çözüme en yakın, negatif ideal çözüme ise en uzak olmasıdır. (Chen ve Chen, 2010) TOPSIS yöntemi, karar vericiler tarafından sıkça kullanılmaktadır. Bunun nedeni ise, sınırlı sayıda öznel girdiye ihtiyaç duymasıdır. Yöntemde kullanılan tek öznel değişken faktör ağırlıklarıdır. Basit ve anlaşılabilir olması ve iyi bir hesaplama etkinliğine sahip olması bu yöntemin temel özellikleridir. (Yeh, 2002)

TOPSIS yöntemi sürecinde eşit ağırlık kullanılabileceği gibi AHP-ANP veya farklı bir yöntem ile kriter ağırlıklarının belirlenmesi ile de uygulanabilir. Genel TOPSIS

\begin{tabular}{|c|c|c|}
\hline Adımlar & Açıklama & Formülasyon \\
\hline Adım-1 & $\begin{array}{l}\text { Karar Matrisinin }(A) \\
\text { oluşturulması }\end{array}$ & $A_{i j}=\left[\begin{array}{ccc}a_{11} & \ldots & a_{1 n} \\
\ldots & \ldots & \ldots \\
a_{m 1} & \ldots & a_{m n}\end{array}\right]$ \\
\hline Adım-2 & $\begin{array}{l}\text { Standart Karar Matrisinin } \\
\text { (Rij) Oluşturulması }\end{array}$ & $\mathrm{r}_{\mathrm{ij}}=\frac{a_{i j}}{\sqrt{\sum_{k=1}^{m} a_{k j}^{2}}}$ \\
\hline Adım-3 & $\begin{array}{l}\text { Ağırlıklı Standart Karar } \\
\text { Matrisinin (V) Oluştu- } \\
\text { rulması }\end{array}$ & $V_{i j}=\left[\begin{array}{ccc}w_{1} r_{11} & \ldots & w_{n} r_{1 n} \\
\cdots & \ldots & \ldots \\
w_{1} r_{m 1} & \ldots & w_{n} r_{m n}\end{array}\right]$ \\
\hline Adım-4 & $\begin{array}{l}\text { İdeal }\left(A^{+}\right) \text {ve Negatif } \\
\text { İdeal }\left(A^{-}\right) \text {Çözümlerin } \\
\text { Oluşturulması }\end{array}$ & $\begin{array}{l}A^{+}=\left\{\left(\max _{i} v_{i j}|j \in J|\right),\left(\min _{i} v_{i j} \mid j \in\right.\right. \\
\left.\left.J^{\prime} \mid\right)\right\} \\
A^{-}=\left\{\left(\min _{i} v_{i j}|j \in J|\right),\left(\max _{i} v_{i j}\left|j \in J^{\prime}\right|\right)\right\}\end{array}$ \\
\hline Adım-5 & $\begin{array}{l}\text { Ayrım Ölçütlerinin He- } \\
\text { saplanması (Pozitif ayrım } \\
\text { ölçütü: } S_{i}^{+} \text {ve negatif ayrım } \\
\text { ölçütü: } S_{i}^{-} \text {) }\end{array}$ & $\begin{aligned} S_{i}^{+} & =\sqrt{\sum_{j=1}^{n}\left(v_{i j}-v_{j}^{*}\right)^{2}}, S_{i}^{-} \\
& =\sqrt{\sum_{j=1}^{n}\left(v_{i j}-v_{j}^{-}\right)^{2}}\end{aligned}$ \\
\hline Adım-6 & $\begin{array}{l}\text { İdeal Çözüme Göreli } \\
\text { Yakınlığın }\left(C_{i}\right) \text { Hesaplan- } \\
\text { ması }\end{array}$ & $C_{i}^{*}=\frac{S_{i}^{-}}{S_{i}^{-}+S_{i}^{*}}$ \\
\hline
\end{tabular}
yöntemi, 6 adım olup Tablo 5'te adımlar açıklama ve formülasyonları ile birlikte verilmiştir.

Tablo 5. TOPSIS Adımları

AHP ve TOPSIS yöntemleri ayrı ayrı kullanılabildiği gibi birbirleri ile entegre edilmiş bir şekilde de uygulanabilmektedir ve literatürde birlikte kullanılan çalışmalar mevcuttur. Çeşitli uygulamalarda birlikte kullanılan AHP-TOPSIS yöntemlerinin geniş bir kullanım alanı vardır. AHP ve TOPSIS yöntemlerini, Supçiller ve Deligöz (2018), tedarikçi seçiminde; Uslu vd. (2017), okul yeri seçiminde; Özcan vd. (2017), bakım planlamada; Arıbaş ve Özcan (2016), araştırma projelerinin değerlendirilmesinde; Eren ve Özder (2016), içecek firması için tedarikçi 
seçimi; Karaatlı vd. (2016), tur operatörü seçimi; Samut (2016), performans değerlendirme; Alağaş vd. (2016), ana haber bültenlerinin değerlendirilmesinde; Ömürbek vd. (2016), uzmanlık alanı seçiminde; Geyik vd. (2016), kitap basımevi seçiminde; Acun ve Eren (2015), oyuncu performanslarının değerlendirilmesinde ve Gergin ve Baki (2015), Türkiye'deki bölgelerin lojistik performanslarının değerlendirmesinde Hamurcu ve Eren (2018) elektrikli otobüs seçiminde kullanmışlardır.

\section{UYGULAMA: AKADEMIK PERFORMANS DEĞERLENDIRME VE YENI BIR ÖNERI}

Önerilen model bir devlet üniversitesinde uygulanmıştır. Üniversite, Mühendislik Fakültesi, Fen-edebiyat Fakültesi, Eğitim Fakültesi, Tıp Fakültesi, Diş Hekimliği Fakültesi, Sağlık Bilimleri Fakültesi, Spor Bilimleri Fakültesi, Veterinerlik Fakültesi, Güzel Sanatlar Fakültesi, Veterinerlik Fakültesi, İktisadi ve İdari Bilimler Fakültesi ve İslami İlimler Fakültesi olmak üzere 12 fakülteden oluşmaktadır. Ayrıca 3 enstitüye sahiptir. 1046 akademik personel ve yaklaşı 40 bin öğrenciye sahiptir. Tablo 6 da fakülteler ve bu fakültelere ait birimler gösterilmektedir. Tablo 7'de de akademik personel sayısı gösterilmektedir.

\begin{tabular}{|c|c|c|c|c|}
\hline Sira & Fakülte & $\begin{array}{l}\text { Sembolik } \\
\text { Gösterim }\end{array}$ & $\begin{array}{l}\text { Bölüm } \\
\text { Sayısı }\end{array}$ & $\begin{array}{l}\text { Alt Bölüm } \\
\text { Sayısı }\end{array}$ \\
\hline 1 & Diş Hekimliği Fakültesi & DHF & 2 & 9 \\
\hline 2 & Eğitim Fakültesi & $\mathrm{EF}$ & 5 & 10 \\
\hline 3 & Fen Edebiyat Fakültesi & FEF & 14 & 17 \\
\hline 4 & Güzel Sanatlar Fakültesi & GSF & 5 & 5 \\
\hline 5 & Hukuk Fakültesi & $\mathrm{HF}$ & 1 & 2 \\
\hline 6 & $\begin{array}{c}\text { İktisadi ve İdari Bilimler } \\
\text { Fakültesi }\end{array}$ & IiBF & 6 & 6 \\
\hline 7 & İslami İlimler Fakültesi & iif & 3 & 3 \\
\hline 8 & Mühendislik Fakültesi & MF & 7 & 7 \\
\hline 9 & SBF & F9 & 6 & 6 \\
\hline 10 & SP & F10 & 4 & 4 \\
\hline 11 & TP & F11 & 2 & 36 \\
\hline 12 & VF & $\mathrm{F} 12$ & 5 & 20 \\
\hline Toplam & 12 Fakülte & & 60 & 125 \\
\hline
\end{tabular}

Tablo 7. Fakültelerin Akademik Personel Sayıları

\begin{tabular}{|c|c|c|c|c|c|c|}
\hline $\begin{array}{c}\text { Sayı } \\
\text { Fakül- } \\
\text { teler }\end{array}$ & Prof. Dr. & Doç. Dr. & Dr. Öğr. Üyesi. & Arş. Gör. & Diğer & Toplam \\
\hline DHF & 7 & 4 & 14 & 51 & 3 & 79 \\
\hline EF & 6 & 18 & 25 & 20 & 2 & 71 \\
\hline FEF & 42 & 24 & 60 & 45 & 8 & 179 \\
\hline GSF & 1 & 2 & 9 & 7 & 8 & 27 \\
\hline HF & 6 & 2 & 17 & 22 & $\ldots-$ & 47 \\
\hline iiBF & 18 & 8 & 31 & 33 & 2 & 92 \\
\hline iiF & 1 & 4 & 15 & 10 & $\ldots-$ & 30 \\
\hline MF & 14 & 11 & 30 & 41 & 2 & 98 \\
\hline SBF & 2 & 5 & 17 & 19 & 3 & 46 \\
\hline SP & 2 & 3 & 11 & 6 & 16 & 38 \\
\hline TP & 45 & 19 & 61 & 157 &.-- & 282 \\
\hline VF & 20 & 15 & 11 & 10 & 2 & 58 \\
\hline Top- & 164 & 115 & 301 & 421 & 45 & 1046 \\
\hline lam & & & & & & \\
\hline
\end{tabular}

\subsection{Araştırma Metodolojisi}

Çalışma akademik teşvik ödeneği başvurusu için hesaplanan akademik faaliyet puanları baz alınarak çok kriterli karar verme yöntemleri ile üniversitede önce fakültelerinin sıralanması ve daha sonra önerilen modelin bölüm ve personel bazında da uygulanabilirliğini göstermek için örnek bir uygulama, mühendislik fakültesinde bölümlerin sıralanması için yapılmıştır. Mühendislik fakültesi içinde aynı zamanda akademik unvana göre sıralamada yapılıp akademisyenlerin performansları değerlendirilmiştir.

Çalışmanın araştırma metodolojisi Şekil 2'de gösterilmektedir. Performansın ölçümü/değerlendirilmesi/sıralanması olarak belirlenen çalışmanın amacı doğrultusunda değerlendirilmeye tabi tutulacak fakülte, bölüm ve akademik unvanların belirlenmesi ve akabinde bu birim ve unvanlara ait YÖK sistemine girilen akademik teşvik puanlarının sistemden alınması olarak süreç devam etmiştir. Fakülte bazında önem seviyeleri değişen akademik faaliyet kalemleri için uzman görüşleri ve literatür taranarak belirlenen 4 kriter doğrultusunda bu faaliyetler AHP yöntemi ile ağırlıklandırılmıştır.

AHP yöntemi ile ağırlıklandırılan akademik faaliyetlerin önemi fakülte bazında farklılık gösterecektir. Bu açıdan fakülte bazında farklı önem seviyeleri bu ağırlıklandırma süreci ile aynı çatı altında değerlendirmek daha doğru sonuçlar ortaya koyacaktır. Fakülte bazında belirlenen akademik teşvik puanları toplanarak fakültelerin akademik faaliyet puanları toplamı TOPSIS yöntemi için başlangıç matrisini oluşturacaktır. Bu yöntem süreci ile dışarıdan ayrı bir müdahale olmadan analitik süreç işleyecek ve en uygun sıralama ortaya konulacaktır. Fakülteler için uygulanan bu süreç mühendislik fakültesi bölümleri ve akademik unvanlarına göre sıralamalar da yapılmıştır. Önerilen model ilerleyen aşamalarda anlatılmıştır.

\subsection{Değerlendirme Kriterlerinin Belirlenmesi}

Akademik performans kriterleri, akademisyenlerin performanslarını doğrudan ve mümkün olan en net biçimde ifade edilmesine olanak sağlamalıdır. Akademisyenlerin, kurumsal ve bilimsel hedeflere karşılık hizmetleri ne kadar iyi yürüttüğünü gösteren nicel ve nitel ifadelerdir. Akademisyenlerin performanslarının yönetilmesi ya da bu sürecin ilk aşaması olan akademik performans kriterlerinin belirlenmesi kurumun etkinliğinin, etkililiğinin, ekonomikliğinin, kalitesinin, ya da genel olarak başarısının artırılmasında önemli bir yer tutmaktadır. Akademik performans kriterlerinin doğru seçimi, performans yönetim sistemi ile elde edilen verilerin güvenilirliği ve geçerliliğinde etkili olacaktır. Elde edilen bilgilerin güvenilir ve ölçülmek istenen nitelikleri ölçebilmesi ancak performans kriterlerinin doğru seçilmesi ile mümkün olacaktır. Örneğin yalnız yayınlar ile ilgili akademik kriterler belirlenirse yalnız bu alanla ilgili veri elde edilebilir. Hem yayınlar hem eğitim ve öğretime ilişkin kriterler belirlenirse her iki alanla ilgili veri elde edilebilir. Tüm akademisyen- 


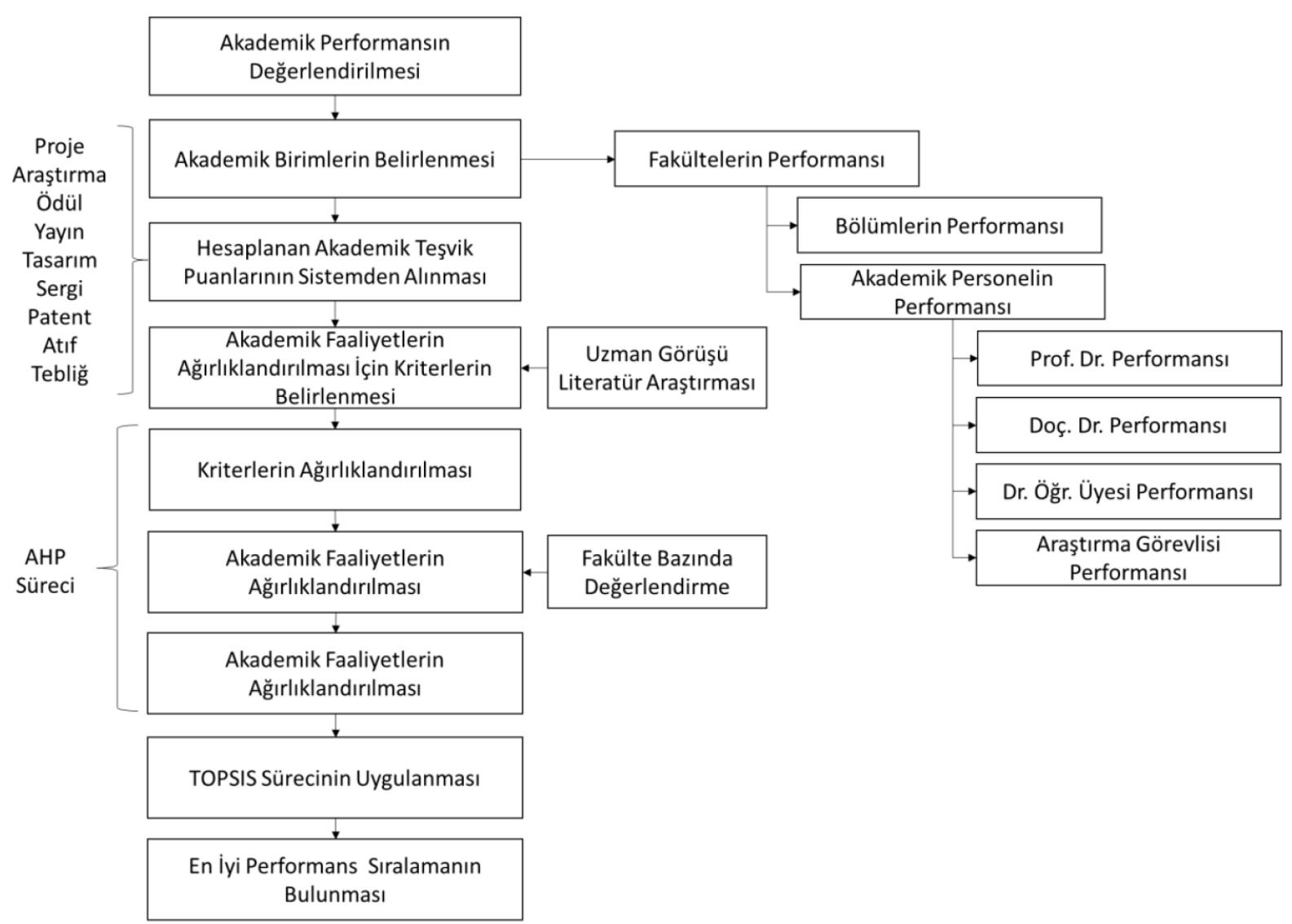

Şekil 2. Araştırma Metodolojisi

ler için uygulanabilecek tek tip akademik performans kriterleri ile değerlendirme bütünlüğünü savunmak doğru değildir. Fakülte ya da akademik birime göre farklılaştırılmış/özelleştirilmiş akademik performans kriterleri daha faydalı olabilir (Çeliksoy, 2009).

Tablo 8. Değerlendirme Kriterleri

\begin{tabular}{|c|l|l|}
\hline Nu. & \multicolumn{1}{|c|}{ Kriterler } & \multicolumn{1}{c|}{ Açıklama } \\
\hline 1. & $\begin{array}{l}\text { Bilimsel } \\
\text { Üretkenlik }\end{array}$ & $\begin{array}{l}\text { Özgün ve yazılı yayınlar ile bilimsel çıktı sayııının arttı- } \\
\text { rılması ile bilim toplumunda öncülüğü üstenebilecek } \\
\text { faaliyetelerdir. }\end{array}$ \\
\hline 2. & Ar-Ge & $\begin{array}{l}\text { Ortaya konulacak faaliyetlerin yenilik içermesi ve } \\
\text { mevcut durumda fiziksel bir gelişmenin sağlanması ile } \\
\text { büyük, farklı yeniliklerin sağlanmasıdır. }\end{array}$ \\
\hline 3. & Toplumsal \\
Yarar & $\begin{array}{l}\text { İcra edilen ortaya konan faaliyetlerin sonucunda top- } \\
\text { lumsal faydanın sağlanması. Bu uzun süreli veya kısa } \\
\text { süreli olabileceği gibi istenen sürekliliğin sağlanmasıdır. }\end{array}$ \\
\hline 4. & $\begin{array}{l}\text { Akademik } \\
\text { Saygınlık }\end{array}$ & $\begin{array}{l}\text { Ortaya konan faaliyetlerin, kişinin akademik saygınlığı- } \\
\text { nı arttırııı faaliyet olması. Tanınırlığının arttırılması ve } \\
\text { bilimsel toplumda kendine yer bulabilecek faaliyetlerin } \\
\text { gerçekleştirilmesi. }\end{array}$ \\
\hline
\end{tabular}

Akademik faaliyetlerin önemleri fakülte bazında değişmektedir. Fakülteler için akademik faaliyetler farklı önem önceliklerine sahiptirler. Ancak akademik teşvik ödeneği için hesaplanan puanlar için böyle bir ayrım yapılmamaktadır. Yani akademik faaliyetler fakülteler için farlı önem seviyelerine sahiptir. Akademik teşvik ödeneği toplam puanları fakülte bazında karşılaştırılması bu durumda anlamlı olmayacaktır. Önerilen bu model ile fakülte bazında 4 ana kriter ile belirlenen akademik faaliyetlerin önem seviyeleri performans değerlendirmesinde yol gösterecektir. Bu çalışmada tüm fakültelerin tek modelde değerlendirilebilmesi için akademik faaliyetleri 4 ana kriter bazında değerlendirerek belirli bir çerçeveye girmeleri sağlanmıştır. Belirlenen kriterler uzman görüşü ve literatürden yararlanılarak; bilimsel üretkenlik, toplumsal yarar, Araştırma-Geliştirme (AR-GE) ve akademik saygınlık olmak üzere 4 tanedir. Kriterlerin açıklamaları Tablo 8'de verilmiştir.

\subsection{Hiyerarşi Yapısı}

Karar hiyerarşisi, problemde seçim sürecinden ziyade, akademik faaliyetlerin önem seviyelerinin bulunmasını kapsamaktadır. Bu yüzden hiyerarşide yer alan hedef akademik faaliyetlerin önem seviyelerinin bulunmasıdır. Karar hiyerarşisinde bir alt seviyede değerlendirme kriterleri ve en alt seviyede alternatifler statüsünde yer alan akademik faaliyetlerdir. Karar hiyerarşisi Şekil 3'te gösterilmektedir.

\section{AKADEMIK TEŞVIK PUANI TEMELLI PERFORMANS DEĞERLENDIRME MODEL ÖNERISI}

Akademik performans kriterleri özellikle sayısal olarak ifade edilebilecek faktörler olarak ele alınmaktadır. Niceliğe dayalı yaklaşımlar; öğretim üyesi başına düşen öğrenci sayısı, öğretim üyeleri tarafından yapılan yayın sayısı, kütüphanedeki kitap ve süreli yayın sayısı, bilgisayar, laboratuvar ve benzeri araç-gereç sayısı, vb. sayısal verilere önem vermektedirler. Ancak araştırma, verilen eğitim öğretim, üniversiteye hizmet, topluma hizmet, toplumda tanınmışlık gibi hizmet alanları kriterlerin de eklenerek 


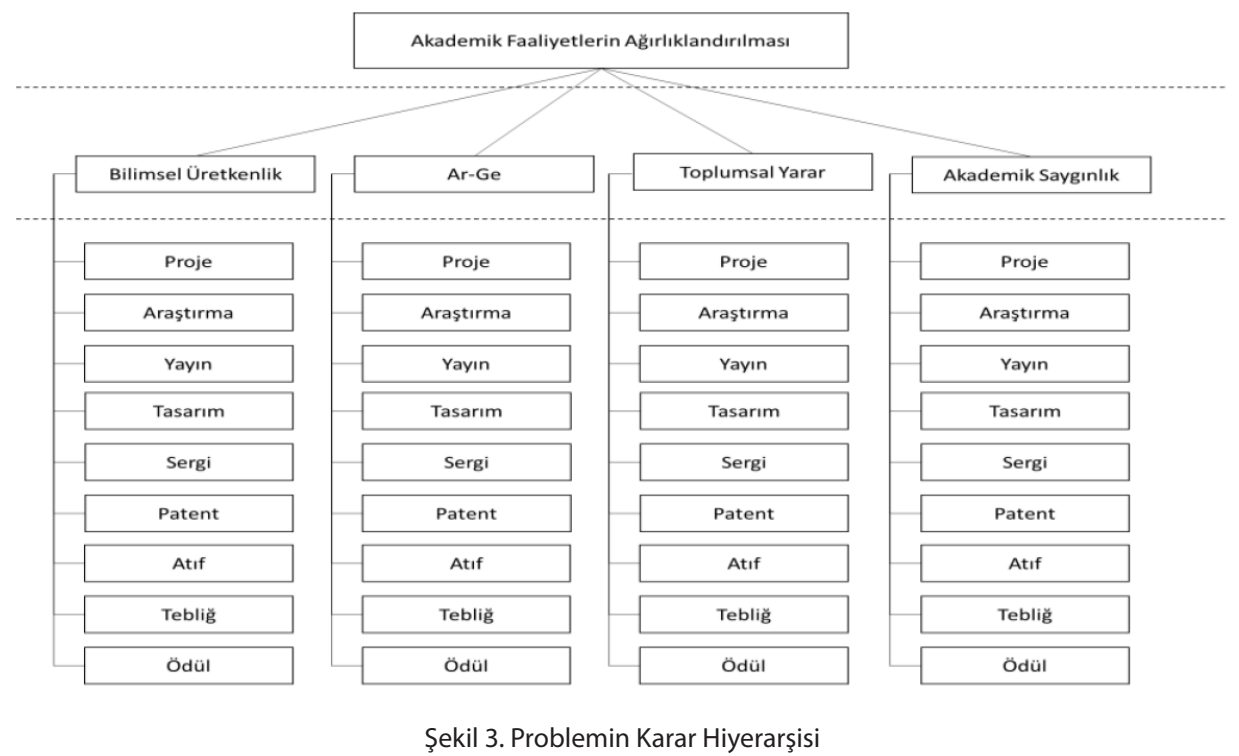

bütüncül bir yaklaşım daha doğru değerlendirmeler ortaya koyacaktır.

Literatürde çok çeşitli değerlendirme, ölçüm, sıralama modelleri vardır. Ancak 2016 yılından beri uygulanmakta olan akademik teşvik temeli bir model henüz ortaya konulmamıştır. Yapılmış değerlendirmelerde daha çok yayın sayısı, atıf sayısı gibi ölçülebilen faaliyetlerin sayısı dikkate alınmıştır. Ancak daha öncede belirttiğimiz gibi bu durum çok da doğru, yeterli bir değerlendirme ortaya koyamamaktadır.

Fakültelerin sıralanmasında ortaya konulacak olan fakülte puanları AHP ile ağırlıklandırılmıştır. Ağırlıklandırma uzman akademik personel görüşü doğrultusunda yapılmıştır. Akademik uzmanlar 3 Endüstri mühendisi, $2 \mathrm{Ma-}$ kine mühendisi, 3 eğitim fakültesi olmak üzere 8 kişiden oluşmaktadır. Belirlenen 4 kriter önce kendi arasında ve daha sonra bu kriterler başlığında A-B ve C olarak 3 gruba ayrılan fakülteler bazında akademik teşvik puanlamasına konu olan 9 başlık ağırlıklandırıldı. Bu ağırlıklandırma işleminden sonra:

Akademik teşvik ödeneğinde yer alan; "Akademik teşvik ödeneğinin hesaplanması MADDE 7- (1) Akademik teşvik ödemesi, en yüksek Devlet memuru brüt aylık tutarının; profesör kadrosunda bulunanlar için \%100'üne, doçent kadrosunda bulunanlar için \%90'ına, yardımcı doçent kadrosunda bulunanlar için \%80'ine, araştırma görevlisi, öğretim görevlisi, okutman, uzman, çevirici ve eğitim-öğretim planlamacısı kadrosunda bulunanlar için \%70'ine, akademik teşvik puanının yüze bölünmesiyle bulunacak oranın uygulanması suretiyle hesaplanır [Akademik teşvik ödemesi tutarı = en yüksek Devlet memuru brüt aylığ $\mathrm{x}$ akademik kadro unvanlarına göre belirlenmiş olan oran x (akademik teşvik puanı/100)]" maddesinden hareketle her faaliyet için fakültede görevli ((Toplam Prof. Dr. Sayısı) *1,00+(Toplam Doç. Dr. Sayısı) *0,9+(Toplam Dr. Öğr. Üyesi Sayısı) *0,8+(Toplam Araştırma Görevlisi Sayısı) *0,7) olarak ayrı ayrı hesaplama sonucunda bulunan akademik personel sayısına oranlanarak bulunur.
Örneğin; Fakültenin akademik teşvikten yararlanan personelinin toplam proje puanı=300 olsun. Fakültede görevli Prof. Dr. Sayısı=6, Doç. Dr. sayısı=10, Dr. Öğr. Üyesi Sayısı=10 ve Arş. Gör. sayısı=20 olsun. Bu durumda;

Fakültenin proje puanı $=300 /$

$((6 * 1,00+10 * 0,9+10 * 0,8+20 * 0,7)=300 / 37=8,1$ olarak hesaplanır.

$\mathrm{Bu}$ işlem diğer akademik faaliyetleri için de tekrarlanarak fakültenin akademik teşvik ödeneği puanı bulunur. Her fakülte için bulunan bu puanlar TOPSIS yöntemi için başlangıç matrisini oluşturacaktır. Daha sonra TOPSIS yöntemi ile en iyi çözüm/sıralama ortaya konularak fakültelerin performansları sıralanır. Fakültelerin gruplandırılması Tablo 9'da gösterilmektedir. Eğitim fakültesinin birçok bölümü fen bilimleri alanında olduğu için bu alanda değerlendirilmeye alınmıştır. Bu önerilen model bölüm bazında değerlendirilirken bölümde yer alan akademik personel sayısı yukarıda belirtildiği gibi aynen hesaplanır. Ancak Bölüm bazında akademik unvan temelinde değerlendirmede her unvana ait toplam personel sayısına direkt bölünerek puan bulunur.

Tablo 9. Fakültelerin gruplandırılması

\begin{tabular}{|c|c|c|c|}
\hline Sira & Grup & Açıklama & Fakülte \\
\hline \multirow{3}{*}{1} & \multirow{3}{*}{ A } & \multirow{3}{*}{ Fen bilimleri alanı } & Mühendislik Fakültesi \\
\hline & & & Fen-Edebiyat Fakültesi \\
\hline & & & Eğitim Fakültesi \\
\hline \multirow{5}{*}{2} & \multirow{5}{*}{ B } & \multirow{5}{*}{ Sağlık bilimleri alanı } & TIP Fakültesi \\
\hline & & & Diş Hekimliği Fakültesi \\
\hline & & & Sağlık Bilimleri Fakültesi \\
\hline & & & Spor bilimleri Fakültesi \\
\hline & & & Veterinerlik Fakültesi \\
\hline \multirow{4}{*}{3} & \multirow{4}{*}{ C } & \multirow{4}{*}{ Sosyal bilimler alanı } & Güzel Sanatlar Fakültesi \\
\hline & & & Hukuk Fakültesi \\
\hline & & & İktisadi ve İdari Bilimler Fakültesi \\
\hline & & & İslami İlimler Fakültesi \\
\hline
\end{tabular}

Her fakülte için yapılan ağırlıklandırma sonucunda ortaya çıkan akademik faaliyetlerin ağırlıkları Tablo 11'da gösterilmektedir. Değerlendirmede sadece Prof. Dr., Doç. Dr., 
Dr. Öğr. Üyesi ve araştırma görevlisi personelleri dikkate alınmıştır. Tablo 11'de bulunan değerler 4 kriter bazında A-B ve C gruplarının ağırlıklarıdır. Bu grupların ağırlıkları Tablo 10'da gösterilen kriterlerin önem ağırlıkları ile bu 4 kriter üzerinden değerlendirilen 9 akademik faaliyetin fakülte bazında bulunan ağılıklarının matris çarpımı sonucunda elde edilen ağırlıklardır.

Akademik teşvik ödeneği puanlarının hesaplanması ile elde edilen değerler TOPSIS başlangıç matrisini oluşturmaktadır. TOPSIS başlangıç matrisi Tablo 12'de gösterilmektedir. Tablo 12'de yer alan 0,000 değerleri belirtilen faaliyet alanında hiçbir çalışma yapılmadığını gösterir. Sürecin işletilmesi ile sırası ile Tablo 13'de ağırlıklı matris ve Tablo 14 'te süreç sonun da ortaya çıkan fakültelerin performans sıralamaları gösterilmektedir. Aynı zamanda değerlendirilebilecek 3 faklı değerlendirme türü ile de karşılaştırma yapılarak sonuçlar Tablo 15 ’te gösterilmektedir.

Toplam akademik teşvik puanına (TATP) göre sıralama, fakültelerin personellerinin hesaplanan akademik teşvik puanlarının toplamına göre sıralamadır. Akademik teșvik alan personel oranına (ATAPO) göre sırama, şartları sağlayarak akademik teşvik ödeneği alan personelin toplam personele oranıdır. Ortalama akademik teşvik puanına (OTATP) göre sıralama, toplam akademik teşvik ödeneği puanının teşvik alan fakülte/bölüm personeline orandır.

Karşılaştırma tablosunda görüldüğü gibi bu çalışmada önerilen model diğer farklı modelleri bünyesinde barındıran ve birçok değerlendirme türünü aynı anda bir mo-

Tablo 10. Kriterin İkili Karşılaştııılması ve Önem Seviyeleri

\begin{tabular}{|c|c|c|c|c|c|}
\hline Kriterler & Bilimsel Üretkenlik & Ar-Ge & Toplumsal Yarar & Akademik Saygınlık & Önem seviyesi \\
\hline Bilimsel Üretkenlik & 1,000 & 0,333 & 0,333 & 0,333 & 0,099 \\
\hline Ar-Ge & 3,000 & 1,000 & 1,000 & 3,000 & 0,365 \\
\hline Toplumsal Yarar & 3,000 & 1,000 & 1,000 & 3,000 & 0,365 \\
\hline Akademik Saygınlık & 3,000 & 0,333 & 0,333 & 1,000 & 0,172 \\
\hline \multicolumn{7}{|c|}{ Tutarlılık Oranı 0,059 } \\
\hline
\end{tabular}

Tablo 11. Fakülte Bazında Akademik Faaliyetlerin Ağırlıkları

\begin{tabular}{|c|c|c|c|c|c|c|}
\hline Faaliyet & DHF & $\mathrm{EF}$ & FEF & GSF & HF & iiBF \\
\hline Araştırma & 0,0949 & 0,0749 & 0,0749 & 0,0849 & 0,0849 & 0,0849 \\
\hline Yayın & 0,2119 & 0,1019 & 0,1019 & 0,2419 & 0,2419 & 0,2419 \\
\hline Tasarım & 0,0225 & 0,0725 & 0,0725 & 0,0725 & 0,0725 & 0,0725 \\
\hline Atıf & 0,0702 & 0,0402 & 0,0402 & 0,071 & 0,071 & 0,071 \\
\hline Tebliğ & 0,0974 & 0,0574 & 0,0574 & 0,1066 & 0,1066 & 0,1066 \\
\hline Ödül & 0,0801 & 0,0601 & 0,0601 & 0,0901 & 0,0901 & 0,0901 \\
\hline Faaliyet & iiF & $M F$ & $S B F$ & $S F$ & $T F$ & $V F$ \\
\hline Yayın & 0,2419 & 0,1019 & 0,2119 & 0,2119 & 0,2119 & 0,2119 \\
\hline Tasarım & 0,0725 & 0,0725 & 0,0225 & 0,0225 & 0,0225 & 0,0225 \\
\hline Sergi & 0,0901 & 0,0710 & 0,0301 & 0,0301 & 0,0301 & 0,0301 \\
\hline Patent & 0,2003 & 0,3594 & 0,2703 & 0,2703 & 0,2703 & 0,2703 \\
\hline Atıf & 0,071 & 0,0402 & 0,0702 & 0,0702 & 0,0702 & 0,0702 \\
\hline Tebliğ & 0,1066 & 0,0574 & 0,0974 & 0,0974 & 0,0974 & 0,0974 \\
\hline Ödül & 0,0901 & 0,0601 & 0,0801 & 0,0801 & 0,0801 & 0,0801 \\
\hline
\end{tabular}

Tablo 12. TOPSIS Başlangıç Matrisi

\begin{tabular}{|c|c|c|c|c|c|c|c|c|c|}
\hline Fakülteler & Proje & Araştırma & Yayın & Tasarım & Sergi & Patent & Atıf & Tebliğ & Ödül \\
\hline DHF & 6,690 & 0,000 & 10,679 & 0,000 & 0,000 & 0,000 & 9,951 & 4,860 & 0,201 \\
\hline EF & 5,464 & 0,000 & 23,253 & 0,000 & 0,469 & 0,000 & 13,552 & 16,388 & 0,260 \\
\hline FEF & 4,407 & 0,000 & 14,755 & 0,000 & 0,888 & 0,000 & 8,241 & 6,908 & 0,373 \\
\hline GSF & 5,173 & 0,000 & 15,300 & 1,537 & 23,341 & 0,000 & 2,532 & 5,934 & 1,463 \\
\hline HF & 0,815 & 0,000 & 9,465 & 0,000 & 0,000 & 0,000 & 3,367 & 2,776 & 0,367 \\
\hline IiBF & 2,589 & 0,000 & 15,928 & 0,000 & 0,000 & 0,000 & 4,260 & 7,309 & 0,332 \\
\hline IIF & 0,000 & 0,000 & 3,534 & 0,000 & 0,000 & 0,000 & 0,915 & 2,898 & 0,000 \\
\hline MF & 10,222 & 0,000 & 15,364 & 0,000 & 0,000 & 0,000 & 10,285 & 15,337 & 1,312 \\
\hline SBF & 7,606 & 0,000 & 23,405 & 0,000 & 0,000 & 0,000 & 8,552 & 23,349 & 0,507 \\
\hline SF & 2,253 & 0,000 & 13,889 & 0,000 & 1,038 & 0,000 & 4,578 & 9,428 & 0,195 \\
\hline TF & 4,628 & 0,014 & 10,828 & 0,000 & 0,000 & 0,000 & 9,996 & 3,142 & 0,126 \\
\hline VF & 14,888 & 0,000 & 18,889 & 0,000 & 0,000 & 0,000 & 17,373 & 5,843 & 1,257 \\
\hline
\end{tabular}


Tablo 13. Ağırlıklandırılmış Matris

\begin{tabular}{|c|c|c|c|c|c|c|c|c|c|}
\hline Fakülteler & Proje & Araştırma & Yayın & Tasarım & Sergi & Patent & Atıf & Tebliğ & Ödül \\
\hline DHF & 0,8201 & 0,0000 & 2,2628 & 0,0000 & 0,0000 & 0,0000 & 0,6986 & 0,4734 & 0,0161 \\
\hline EF & 0,8884 & 0,0000 & 2,3694 & 0,0000 & 0,0333 & 0,0000 & 0,5448 & 0,9407 & 0,0157 \\
\hline FEF & 0,7166 & 0,0000 & 1,5035 & 0,0000 & 0,0630 & 0,0000 & 0,3313 & 0,3965 & 0,0224 \\
\hline GSF & 0,2204 & 0,0000 & 3,7011 & 0,1114 & 2,1031 & 0,0000 & 0,1798 & 0,6326 & 0,1319 \\
\hline HF & 0,0347 & 0,0000 & 2,2895 & 0,0000 & 0,0000 & 0,0000 & 0,2390 & 0,2959 & 0,0331 \\
\hline IiBF & 0,1103 & 0,0000 & 3,8530 & 0,0000 & 0,0000 & 0,0000 & 0,3025 & 0,7791 & 0,0299 \\
\hline IIF & 0,0000 & 0,0000 & 0,8549 & 0,0000 & 0,0000 & 0,0000 & 0,0650 & 0,3090 & 0,0000 \\
\hline MF & 1,6621 & 0,0000 & 1,5656 & 0,0000 & 0,0000 & 0,0000 & 0,4134 & 0,8803 & 0,0789 \\
\hline SBF & 0,9325 & 0,0000 & 4,9594 & 0,0000 & 0,0000 & 0,0000 & 0,6004 & 2,2742 & 0,0406 \\
\hline SF & 0,2762 & 0,0000 & 2,9431 & 0,0000 & 0,0312 & 0,0000 & 0,3214 & 0,9183 & 0,0156 \\
\hline TF & 0,5674 & 0,0013 & 2,2944 & 0,0000 & 0,0000 & 0,0000 & 0,7017 & 0,3060 & 0,0101 \\
\hline VF & 1,8252 & 0,0000 & 4,0026 & 0,0000 & 0,0000 & 0,0000 & 1,2196 & 0,5691 & 0,1007 \\
\hline
\end{tabular}

Tablo 14. Fakültelerin Sıralanması

\begin{tabular}{|c|c|c|c|c|c|}
\hline Fakülteler & S+ & S- & Ci (S-/(S-+ $\left.S^{*}\right)$ & Yüzde (\%) & Siralama \\
\hline DHF & 0,1840 & 0,0591 & 0,2431 & 0,0715 & 7 \\
\hline EF & 0,1793 & 0,0634 & 0,2614 & 0,0769 & 6 \\
\hline FEF & 0,1909 & 0,0445 & 0,1892 & 0,0556 & 10 \\
\hline GSF & 0,1459 & 0,1420 & 0,4933 & 0,1451 & 1 \\
\hline HF & 0,2036 & 0,0321 & 0,1363 & 0,0401 & 11 \\
\hline IiBF & 0,1926 & 0,0617 & 0,2426 & 0,0714 & 8 \\
\hline IiF & 0,2179 & 0,0004 & 0,0017 & 0,0005 & 12 \\
\hline MF & 0,1724 & 0,1027 & 0,3734 & 0,1099 & 5 \\
\hline SBF & 0,1647 & 0,1128 & 0,4065 & 0,1196 & 3 \\
\hline TF & 0,1910 & 0,0479 & 0,2005 & 0,0590 & 9 \\
\hline VF & 0,1654 & 0,1067 & 0,3921 & 0,1154 & 4 \\
\hline
\end{tabular}

.Tablo 15: Süreçlerin Karşılaştırılması

\begin{tabular}{|c|c|c|c|c|c|c|c|c|}
\hline \multirow{2}{*}{ Bölümler } & \multicolumn{2}{|c|}{ TATP } & \multicolumn{2}{c|}{ OTATP } & \multicolumn{2}{c|}{ ATAPO } & \multicolumn{2}{c|}{ Önerilen Model } \\
\cline { 2 - 9 } & Oran & Sıralama & Oran & Siralama & Oran & Siralama & Oran & Siralama \\
\hline DHF & 0,0615 & 8 & 0,1096 & 1 & 0,0500 & 10 & 0,0715 & 7 \\
\hline EF & 0,1089 & 4 & 0,0900 & 4 & 0,1201 & 4 & 0,0769 & 6 \\
\hline FEF & 0,1687 & 2 & 0,0827 & 6 & 0,0802 & 6 & 0,0556 & 10 \\
\hline GSF & 0,0351 & 9 & 0,0746 & 9 & 0,1228 & 2 & 0,1451 & 1 \\
\hline HF & 0,0196 & 11 & 0,0728 & 10 & 0,0403 & 11 & 0,0401 & 11 \\
\hline IIBF & 0,0722 & 6 & 0,0700 & 11 & 0,0789 & 7 & 0,0714 & 8 \\
\hline IIF & 0,0061 & 12 & 0,0684 & 12 & 0,0210 & 12 & 0,0005 & 12 \\
\hline MF & 0,1332 & 3 & 0,0900 & 3 & 0,1063 & 5 & 0,1099 & 5 \\
\hline SBF & 0,0709 & 7 & 0,0811 & 7 & 0,1338 & 1 & 0,1196 & 3 \\
\hline SF & 0,0289 & 10 & 0,0805 & 8 & 0,0665 & 8 & 0,0590 & 9 \\
\hline TF & 0,2010 & 1 & 0,0870 & 5 & 0,0577 & 9 & 0,1154 & 4 \\
\hline VF & 0,0940 & 5 & 0,0932 & 2 & 0,1225 & 3 & 0,1351 & 2 \\
\hline
\end{tabular}

delde çalıştırılmasına imkân tanımaktadır.

Bu çalışmanın literatüre katkısı, akademik teşvik ödeneği için kullanılan puanlar baz alınarak ve belirlenen 4 kriter üzerinden ağırlıklandırma yapılarak tüm fakülteleri aynı anda değerlendirme imkânı sağlamasıdır. Önerilen model, TATP, ATAPO ve OTATP göre yapılan tek boyutlu değerlendirmeleri tek bir modelde çoklu değerlendirme imkânı sağladı. Akademik personel performansı değerlendirmelerinde genellikle yayın sayısı veya atıf sayısı gibi değerlere bakılıyor. Bu çalışmada akademik teşvik temeline dayandığı için daha kapsamlı bir değerlendirme imkânı sunmuştur. Uygulama sonuçlarına baktığımızda tek boyutlu değerlendirmeler ile yapılan sonuçlar ile önerilen model sonucundaki sıralamalar değişmiştir. GSF (Güzel Sanatlar Fakültesi), TATP'a göre 9; OTATP'a göre 9; ATA-
PO’a göre 2 iken önerilen modelde 1. sırada yer almıştır.

\subsection{Mühendislik Fakültesi Bölümlerinin Akademik Teşvik Tabanlı Sıralanması}

Üniversitenin kökleşmiş ve akademik teşvik kapsamında yer alan faaliyetlerin çoğunu gerçekleştirmiş olan Mühendislik Fakültesi'nde bölüm ve akademik unvan bazında değerlendirmeler yapılmıştır. Mühendislik fakültesinde, makine mühendisliği, inşaat mühendisliği, endüstri mühendisliği, elektrik-elektronik mühendisliği, bilgisayar mühendisliği, metalürji ve malzeme mühendisliği ile biyomühendislik bölümleri olmak üzere toplam 7 bölümde öğretim verilmektedir. Tablo 16'da bölümlerin personel sayıları gösterilmektedir.

Akademik teşvik ödeneğinden yararlanabilmek için akademisyenlerin proje, araştırma, yayın, tasarım, sergi, pa- 
tent, atıf, tebliğ ve ödül bazında toplam 30 puanı aşacak şekilde puan almaları gerekmektedir. Tablo 17'da gösterilen formlar ile her bir personelin akademik teşvik ödeneği puanı hesaplanmıştır. Tablo 17'de örnek bir veri toplama formu gösterilmektedir.

Veri formlarına aktarılan akademik teşvik puanları bölüm bazında ayrı ayrı toplamları Tablo 18'de gösterilmektedir. Bu tablo üzerinden her bölümdeki profesör, doçent doktor, yardımcı doçent doktor ve araştırma görevlisi personelin akademik teşvik yüzdeleri dikkate alınarak çarpılması ile TOPSIS başlangıç matrisi oluşturulmaktadır. TOPSIS sürecinde ise her bir faaliyetin ağırlıkları AHP ile bulunarak sürece dahil edilmiştir. Mühendislik Fakültesi için bulunan faaliyetlerin önem ağırlıkları burada da kullanılmıştır.

Yapılan değerlendirme sonucunda ortaya çıkan TOPSIS sonucu Tablo 19'da gösterilmektedir. En iyi sıralamayı veren bu yöntem sonucunda M1: bilgisayar mühendisliği birinci olmak üzere gösterilen sıralama ortaya çıkmıştır.

Bölüm bazında yapılan performans değerlendirmesinden sonra yine 3 farklı değerlendirme türü ile de karşılaştırma yapılmış ve sonuçlar Tablo 20'de gösterilmektedir. Ayrıca bölümlerde yer alan sadece Prof. Dr., sadece Doç. Dr., sadece Dr. Öğr. Üyesi ve sadece Arş. Gör. baz alınarak akademik unvana göre ayrı ayrı yapılan değerlendirmeler sonucunda ortaya çıkan sıralamalar Tablo 21'de gösterilmektedir. Toplam akademik teşvik puanı, bölümde teşvik alan akademik personel sayısına göre sıralama ve ortalama akademik teşvik puanına göre sıralama olarak 3 faklı değerlendirme sistemi ile karşılaştırılma yapılmıştır.

Net puanlar üzerinden yapılan değerlendirmeler ham puan üzerinden yapılarak ortaya çıkan sıralamalar Tablo 22'de gösterilmektedir. Ayrıca akademik unvanlar arasında yapılan sıralama ise Tablo 23'de gösterilmektedir. Aka-

Tablo 16. Mühendislik Fakültesi Bölümleri

\begin{tabular}{|c|c|c|c|c|c|c|c|c|c|c|}
\hline \multirow[t]{2}{*}{ Mühendislik Bölümleri } & \multicolumn{2}{|c|}{ Prof. Dr. } & \multicolumn{2}{|c|}{ Doç. Dr. } & \multicolumn{2}{|c|}{ Dr. Öğr. Üyesi } & \multicolumn{2}{|c|}{ Arş. Gör. } & \multicolumn{2}{|c|}{ Toplam } \\
\hline & $\begin{array}{c}\text { Toplam } \\
\text { Sayısı }\end{array}$ & $\begin{array}{l}\text { Teşvik } \\
\text { Alan }\end{array}$ & $\begin{array}{l}\text { Toplam } \\
\text { Sayısı }\end{array}$ & $\begin{array}{l}\text { Teşvik } \\
\text { Alan }\end{array}$ & $\begin{array}{l}\text { Toplam } \\
\text { Sayısı }\end{array}$ & $\begin{array}{l}\text { Teşvik } \\
\text { Alan }\end{array}$ & $\begin{array}{l}\text { Toplam } \\
\text { Sayısı }\end{array}$ & $\begin{array}{l}\text { Teşvik } \\
\text { Alan }\end{array}$ & $\begin{array}{c}\text { Personel } \\
\text { Sayısı }\end{array}$ & $\begin{array}{l}\text { Teşvikten } \\
\text { Yararlanan }\end{array}$ \\
\hline Bilgisayar Müh.(M1) & 2 & 1 & 0 & 0 & 3 & 3 & 7 & 7 & 12 & 11 \\
\hline Biyomühendislik (M2) & 3 & 3 & 0 & 0 & 2 & 2 & 3 & 1 & 8 & 6 \\
\hline Elektrik- Elektronik Müh.(M3) & 2 & 2 & 1 & 1 & 6 & 3 & 7 & 5 & 16 & 11 \\
\hline Endüstri Müh.(M4) & 1 & 1 & 4 & 4 & 4 & 2 & 5 & 3 & 14 & 10 \\
\hline İnşaat Müh. (M5) & 3 & 2 & 3 & 1 & 5 & 2 & 8 & 4 & 19 & 9 \\
\hline Makine Müh. (M6) & 3 & 3 & 0 & 0 & 6 & 6 & 9 & 2 & 18 & 11 \\
\hline Metalürji ve Malzeme Müh.(M7) & 1 & 1 & 2 & 2 & 4 & 4 & 3 & 1 & 10 & 8 \\
\hline Toplam Sayısı & 14 & ..- & 11 & -.. & 31 & ..- & 42 & $\ldots$ & 98 & ..- \\
\hline Teşvikten Yararlanan Sayısı & -.- & 13 & ..- & 8 & ..- & 22 & -.- & 23 & -.- & 66 \\
\hline
\end{tabular}

Tablo 17. Mühendislik Fakültesi Akademik Faaliyet Puanları

\begin{tabular}{|c|c|c|c|c|c|c|c|c|c|c|c|c|}
\hline Sıra & Personel & Kıdem & Bölüm & Proje & Araştırma & Yayın & Tasarım & Sergi & Patent & Atıf & Tebliğ & Ödül \\
\hline 1 & $X X X Y$ & Prof. Dr. & Endüstri Müh. & $\ldots$ & $\ldots$ & $\ldots$ & $\ldots$ & $\ldots$ & $\ldots$ & $\ldots$ & $\ldots$ & $\ldots$ \\
\hline 2 & ZXC C & Doç. Dr. & Makine Müh. & $\cdots$ & $\cdots$ & $\ldots$ & $\ldots$ & $\ldots$ & $\ldots$ & $\ldots$ & $\ldots$ & $\ldots$ \\
\hline 3 & ASD F & Arş. Gör. & İnşaat Müh. & $\ldots$ & $\ldots$ & $\ldots$ & $\ldots$ & $\ldots$ & $\ldots$ & $\ldots$ & $\ldots$ & $\ldots$ \\
\hline 4 & İ̧̧L L & Arş. Gör. & Bil. Müh. & $\ldots$ & $\ldots$ & $\ldots$ & $\ldots$ & $\ldots$ & $\ldots$ & $\ldots$ & $\ldots$ & $\ldots$ \\
\hline$\ldots$ & $\ldots$ & $\ldots$ & $\ldots$ & $\ldots$ & $\ldots$ & $\ldots$ & $\ldots$ & $\ldots$ & $\ldots$ & $\ldots$ & $\ldots$ & $\ldots$ \\
\hline$\ldots$ & $\ldots$ & $\ldots$ & $\cdots$ & $\ldots$ & $\ldots$ & $\ldots$ & $\ldots$ & $\ldots$ & $\cdots$ & $\ldots$ & $\ldots$ & $\ldots$ \\
\hline$\ldots$ & $\ldots$ & $\ldots$ & $\ldots$ & $\ldots$ & $\ldots$ & $\ldots$ & $\ldots$ & $\ldots$ & $\ldots$ & $\ldots$ & $\ldots$ & $\ldots$ \\
\hline
\end{tabular}

Tablo 18. Mühendislik Fakültesi Bölümlerin Akademik Faaliyet Puanları

\begin{tabular}{|c|c|c|c|c|c|c|c|c|c|}
\hline Bölümler & Proje & Araştırma & Yayın & Tasarım & Sergi & Patent & Atıf & Tebliğ & Ödül \\
\hline M1 & 162,00 & 0,00 & 142,80 & 0,00 & 0,00 & 0,00 & 44,40 & 281,85 & 10,50 \\
\hline M2 & 45,75 & 0,00 & 129,45 & 0,00 & 0,00 & 0,00 & 157,80 & 48,60 & 0,00 \\
\hline M3 & 98,25 & 0,00 & 238,95 & 0,00 & 0,00 & 0,00 & 172,50 & 220,05 & 36,00 \\
\hline M4 & 90,60 & 0,00 & 191,85 & 0,00 & 0,00 & 0,00 & 145,80 & 232,35 & 15,00 \\
\hline M5 & 147,75 & 0,00 & 204,30 & 0,00 & 0,00 & 0,00 & 93,60 & 192,15 & 18,00 \\
\hline M6 & 60,45 & 0,00 & 176,38 & 0,00 & 0,00 & 0,00 & 154,80 & 201,90 & 30,00 \\
\hline M7 & 178,20 & 0,00 & 123,15 & 0,00 & 0,00 & 0,00 & 71,70 & 57,90 & 0,00 \\
\hline
\end{tabular}

Tablo 19: Bölümlerin Sıralanması

\begin{tabular}{|c|c|c|c|c|c|}
\hline Bölümler & $\mathrm{S}^{+}$ & $\mathrm{S}$ & $\mathrm{Ci}\left(\mathrm{S}-/\left(\mathrm{S}-+\mathrm{S}^{*}\right)\right.$ & Yüzde (\%) \\
\hline M1 & 0,0355 & 0,0794 & 0,6912 & 0,2413 \\
\hline M2 & 0,0883 & 0,0304 & 0,2559 & 0,0893 \\
\hline M3 & 0,0723 & 0,0478 & 0,3980 & 0,1389 \\
\hline M4 & 0,0718 & 0,0389 & 0,3514 & 0,1227 \\
\hline M6 & 0,0731 & 0,0313 & 0,3000 & 0,1047 \\
\hline M7 & 0,0921 & 0,0310 & 0,2516 & 0,0878 \\
\hline
\end{tabular}


demik unvanlar arasında yapılan sıralamada göze çarpan önemli bir nokta söz konusudur. Prof. Dr. unvanına sahip kadro 1. sırada yer alırken 2. sırada Dr. Öğr. Üyesi Unvana sahip personeller gelmektedir. Bu durum doçentliğe atanmak için şartların sağlanmaya çalışılması neticesinde ortaya çıktığı ön görülmektedir. Ayrıca bu noktada, doçentliğini alan akademik personelin çalışma performansında düşüklük olduğu yorumu da yapılabilir.

Fakültelerin, bölümlerin ve akademik personellerin unvan bazında performans sıralamaları tek boyutlu incelenebileceği gibi bu çalışma ile önerilen modelde çeşitli faktörleri tek model de sunma ve değerlendirme imkânı vermektedir. Yapılan performans siralamaları tablolarda gösterilmiştir. Önerilen modelin, tek kriterli değerlendirmelere göre (TATP, OTATP, ATATP) daha etkili sonuçlar verdiği görülmüştür.

\section{SONUÇ VE DEĞERLENDIRME}

Performans yönetimi örgütün daha önceden benimsediği amaç ve hedeflere ulaşmak için izlediği yol ile elde ettiği sonuçların birlikte ölçülüp değerlendirildiği bir bütündür. Kamu yönetiminde performans yönetimi, kamu örgütlerinin sunmakla yükümlü oldukları mal ve hizmetleri yerine getirme ve sunmada kullandığı yol, yöntem ve araçlar bütünüdür.
Akademik performans kriterlerinin kullanımı ile; örgütün etkililiği ve etkinliği artar, hizmet ve üretimin kalitesi gelişir, eğitim ihtiyacı ve bütçesi daha kolay ve doğru biçimde belirlenir, insan kaynaklarının planlanması için gerekli bilgiler güvenilir biçimde elde edilir, bireylerin gelişme potansiyelleri daha rahat izlenebilir, daha kısa süre içinde daha yüksek fayda sağlanabilir, izleyen yıllar için daha yüksek hedefler belirlenebilir, örgütün fiziksel ve beşeri kaynakları daha etkili şekilde kullanılabilir, değişen koşullara daha hızlı tepki verilebilir, kararların zamanında alınmasını ve daha tutarlı olmasını sağlar, bir "sürekli iyileştirme” kültürünün gelişmesine katkıda bulunur.(Çeliksoy 2009).

Yapılan bu çalışmada son 3 yıldır uygulanmakta olan akademik teşvik ödeneği sistemi için kullanılan akademik faaliyetlerin puanlandırılması baz alınarak fakültelerin bölümlerin ve akademik personellerin performansları değerlendirilmiştir. Belirlenen 4 kriter ile akademik faaliyetler AHP yöntemi ile ağırlıklandırılmış ve TOPSIS yöntemi ile akademik teşvik puanları kullanılarak sıralama yapılmıştır. Fakülte bazında ön plana çıkan alanların bu performans değerlendirme önerisi ile tek çatı altında değerlendirilme imkânı sunulmuştur.

Yapılan bu çalışmada, Ar-Ge ve toplumsal yarar kriterlerinin önem sevilerinin yüksek olduğu görülmektedir.

Tablo 20: Süreçlerin Karşılaştırılması

\begin{tabular}{|c|c|c|c|c|c|c|c|c|}
\hline \multirow{2}{*}{ Bölümler } & \multicolumn{2}{|c|}{ TATP } & \multicolumn{2}{|c|}{ ОTATP } & \multicolumn{2}{|c|}{ ATAPO } & \multicolumn{2}{|c|}{ Önerilen Model } \\
\hline & Oran & Sıralama & Oran & Siralama & Oran & Siralama & Oran & Sıralama \\
\hline M1 & 0,1534 & 4 & 0,1316 & 5 & 0,1851 & 1 & 0,2413 & 1 \\
\hline M2 & 0,0912 & 7 & 0,1435 & 4 & 0,1514 & 3 & 0,0893 & 6 \\
\hline M3 & 0,1831 & 1 & 0,1570 & 2 & 0,1388 & 5 & 0,1389 & 3 \\
\hline M4 & 0,1633 & 2 & 0,1541 & 3 & 0,1442 & 4 & 0,1227 & 4 \\
\hline M5 & 0,1568 & 3 & 0,1644 & 1 & 0,0956 & 7 & 0,1047 & 5 \\
\hline M6 & 0,1491 & 5 & 0,1279 & 6 & 0,1234 & 6 & 0,0878 & 7 \\
\hline M7 & 0,1030 & 6 & 0,1215 & 7 & 0,1615 & 2 & 0,2152 & 2 \\
\hline
\end{tabular}

Tablo 21: Bölümlerin Akademik Unvan Durumlarına Göre Ayrı Ayrı Sıralanması

\begin{tabular}{|c|c|c|c|c|c|c|c|}
\hline \multirow{2}{*}{ Akademik Unvan } & \multicolumn{7}{|c|}{ Bölümlerin Performans Sıralaması } \\
\hline & M1 & M2 & M3 & M4 & M5 & M6 & M7 \\
\hline Prof. Dr. & 5 & 3 & 2 & 6 & 4 & 7 & 1 \\
\hline Doç. Dr. & $\ldots$ & ..- & 4 & 1 & 3 & -.. & 2 \\
\hline Dr. Öğr. Üyesi & 1 & 4 & 6 & 5 & 7 & 3 & 2 \\
\hline Arş. Gör. & 1 & 6 & 4 & 5 & 3 & 7 & 2 \\
\hline
\end{tabular}

Tablo 22: Bölümlerin Akademik Unvan Durumlarına Göre Ayrı Ayrı Sıralanması (Ham puan)

\begin{tabular}{|c|c|c|c|c|c|c|c|}
\hline \multirow{2}{*}{ Akademik Unvan } & \multicolumn{7}{|c|}{ Bölümlerin Performans Sıralaması } \\
\cline { 2 - 8 } & M1 & M2 & M3 & M4 & M5 & M6 & M7 \\
\hline Toplam Puan & 1 & 5 & 3 & 4 & 4 & 7 \\
\hline Prof. Dr. & 5 & 3 & 1 & 6 & 3 & $\ldots$ \\
\hline Doç. Dr. &.-- & $\ldots$ & 4 & 1 & 7 & 3 \\
\hline Dr. Öğr. Üyesi & 1 & 4 & 6 & 5 & 2 & 7 & 3 \\
\hline Arş. Gör. & 1 & 6 & 4 & 5 & 3 & 7 \\
\hline
\end{tabular}

Tablo 23: Akademik Unvanlar Arasında Yapılan Sıralama

\begin{tabular}{|c|c|c|c|c|c|}
\hline Unvan & B+ & B- & Ci (S-/(S-+S*) & Sıralama \\
\hline Prof. Dr. & 0,0509 & 0,0884 & 0,6348 & 0,3186 \\
\hline Doç. Dr. & 0,0624 & 0,0483 & 0,4363 & 0,2190 \\
\hline Dr. Öğr. Üyesi & 0,0490 & 0,0601 & 0,5509 & 0,2765 & 3 \\
\hline Arş. Gör. & 0,0882 & 0,0519 & 0,3702 & 0,1858 \\
\hline
\end{tabular}


Daha sonra sırası ile akademik saygınlık ve bilimsel üretkenlik kriterleri gelmektedir. Bu kriterler altında 9 faaliyet üzerinde birleşen akademik faaliyetlerin fakülte bazında değerlendirilerek ortak bir değerlendirme imkânı sunulmuştur. Neticede bu model tek kriterli değerlendirmeler ile karşılaştırıldığında; örneğin TATP’nin da 9. Sırada yer alan Güzel sanatlar fakültesi önerilen bu model ile 1 . sıraya yükselmiştir. Bu duruma Güzel sanatlar fakültesinin patent hariç tüm akademik faaliyetlerden puan almış olmasının sebep olduğu açıktır. Ayrıca bu fakülte sergi faaliyetinde diğer fakültelere göre yüksek puana sahiptir. TATP'de 1. sirada yer alan TIP fakültesi önerilen modelde 4. sırada yer almıştır. Bu duruma akademik teşvik alan personel sayısının düşük olması sebep olmuştur. Bu durumda gösteriyor ki; önerilen model personel sayısını, teşvikten yararlanan personel sayısını, akademik teşvik puanını ve tüm fakülteleri aynı anda dikkate alarak değerlendirme imkanını sunmaktadır.

Çalışmada ayrıca bölüm bazında ve bölümde personel ve fakültede akademik unvan bazında performans sıralama imkânı da sunmaktadır. Yine akademik unvanlar arasında yapılan sıralamada Tablo 22'de gösterildiği gibi Prof. Dr. 1; Dr. Öğr. Üyesi 2, Doç. Dr. 3 ve Arş Gör. 4. Sırada yer almaktadır. Bu sonuçtan da anlaşıldığı gibi araştırma görevlileri yayın ve akademik faaliyetlerden ziyade farklı uğraş (Bölüm işleri veya ders) meşgul oldukları sonucu ile 4. S1rada yer aldıkları görülmekte. Yine Dr. Öğr. Üyesi kadrosunda yer alan personelin atanma kriterlerini sağlamaya çalıştıkları sonucunu buradan çıkarmak mümkün. Doç. Dr kadrosunda bulunan personelin doçentliğe atanmış olmanın rahatlığı yayın sayısında veya akademik faaliyet sayısında düşüşe sebebiyet vermiş olabilir. Son olarak yapılabilecek böyle bir değerlendirme ile fakültelerde akademik faaliyetler için ayrılan kaynağın atanması yapılabilir. Çalışan fakülte ve bölüme daha fazla kaynak verilmesi gibi akademik faaliyetleri daha fazla desteklenebilir veya tam tersi puanı düşük olan geri planda yer alan fakülte veya bölümlere daha fazla kaynak ayrılarak bu birimlerin akademik faaliyetlerde yer alamsı teşvik edilebilir.

Hemen hemen her alanda performans değerlendirmesi büyük önem taşımaktadır. Akademik personellerin veya birimlerin performanslarının değerlendirilmesi de önem arz etmekte ve çeşitli yöntemler kullanılarak ölçüm ve değerlendirmeler yapılmaktadır. Önerilen bu yeni performans değerlendirme/sıralama sistemi ile daha nesnel ve genel değerlendirme süreçleri ile objektiflik sağlanabilecektir. Aynı zamanda tüm fakülteleri aynı anda ve objektif bir değerlendirme yapmak mümkün olacaktır. Uygulanmakta olan akademik teşvik sistemi sonuçları önerilen bu yöntem ile tek payda da toplanabilecektir.

Gelecek çalışmalarda ANP-VIKOR-PROMETHEE-TOPSIS karma modelleri ayrı ayrı uygulanıp sonuçları üzerinde tartımalar yapılabilir. Özel üniversite ve yüksek okullarda da uygulanabilecek bu model üniversitelerin (Kamu-Vakıf) performanslarının değerlendirilmesinde de yeni bir sıralama modeli olarak kullanılabilir. Gelecek çalışmalar için akademik faaliyetlerin alt seviyelerine de girilerek veya her bir başlık altında ayrı bir değerlendirme süreci uygulanabilir.

Akademik teşvik ödeneği sisteminin de geliştirilmeye açık bir sistem olduğu görülmektedir. Ortaya konulabilecek ilişkiler doğrultusunda akademik faaliyetlerin her biri için mevcut belirlenmiş olan 30 puan sınırı, akademik faaliyetlerin birbirileri ile ilişkileri paralelinde yeniden güncellenebilir ve esnetilebilir. Ayrıca, yapılacak yeni araştırmalar için, atıf sayıları ve dergi $\mathrm{H}$-index’ine 4 kriter arasında yer verilebilir. Bu ilişkiler doğrultusunda puan sınırlaması yapılabilecek formül dahilinde revize edilebilir. Aynı zamanda bazı akademik faaliyetlerde hiç puan alınmadığı bu alanlarda hiç çalışmaların yapılmadığ1 görülmektedir. Bu alanların önemi vurgulanarak veya değerlendirmeden çıkarılarak sistemde güncelleme yapılabilir. Yapılan değerlendirme sonucunda mevcut teşvik sisteminin geliştirilmesi ve akademik faaliyetlerin birbiri ile belirli bir oran dahilinde hesaba katılmaları daha uygun olacaktır. Ham puan ile net puan arasındaki açıklığın böylece elimine edilmesi sağlanmış olacaktır. Performans değerlendirme sürecinin zor ve uzun bir süreç olması, bu alanda daha fazla çalışma yapılmasını gerektirmektedir.

\section{KAYNAKÇA}

Acun, O. Ve Eren, T., (2015). Spor Toto Süper Ligi'nde Forvet Oyuncularının Performanslarının Çok Ölçütlü Karar Verme Yöntemleri İle Değerlendirilmesi. Kırıkkale Üniversitesi Sosyal Bilimler Dergisi, 5(2).

Ağaç, G. ve Birdoğan, B (2016). Sağılı Alanında Çok Kriterli Karar Verme Teknikleri Kullanımı: Literatür İncelemesi. Hacettepe Sağlık İdaresi Dergisi, 19(3), 343-363.

AkademikTeşvikÖdeneği Yönetmeliği.(2017).01.Şubat 2017.tarihinde <http://yok.gov.tr/documents/10279/30318223/ Akademik_Tesvik_Odenegi_Yonetmeligi_31_12_2016_ Resmi_Gazete_Yayin_Tarihi.pdf $>$ adresinden erişildi.

Alağaş, H. M., Bedir, N., Mermi, Ö. S., Kızıltaş, Ş., \& Eren, T. (2016). Ana Haber Bültenlerinin AHP-TOPSIS ile Değerlendirilmesi. 2. Uluslararası Medya Çalışmaları Kongresi, 20-23.

Alağaş, H. M., Mermi, Ö. S., Kızıltaş, Ş., Eren, T., \& Hamurcu, M. (2017). Analitik Hiyerarşi Prosesi ve Hedef Programlama Yöntemi ile Reklam Stratejisi Seçimi: Mobilya Firması Örneği. 5th International Symposium on Innovative Technologies in Engineering and Science, 516-525.

Alparslan, A. M. (2014). Öğretim Elemanlarının İşlerinden Tatmin, Üniversitelerinden Memnun ve Gönüllü Olmalarındaki Öncüller: Mehmet Akif Ersoy Üniversitesi'nde Bir Araştırma. Mehmet Akif Ersoy Üniversitesi Sosyal Bilimler Enstitüsü Dergisi, 6(11), 82-101.

Aly, M. F., Attia, H. A., \& Mohammed, A. M. (2014). Prioritizing faculty of engineering education performance by using AHP-TOPSIS and Balanced Scorecard Approach. International journal of engineering science and innovative technology, 3(1), 11-23.Arıbaş, M., \& Özcan, U. (2016). Akademik Araştırma Projelerinin AHP ve TOPSIS Yöntemleri Kullanılarak Değerlendirilmesi. Politeknik Dergisi, 19(2), 163-173.

Ateş, H., ve Akpınar, A.G.A. (2017). Türkiye'de Kamu Yöneti- 
mi Bölümü Akademisyenlerinin Performansları: İki Kriter Çerçevesinde Bir İnceleme. Yüzüncü Yıl Üniversitesi Sosyal Bilimler Enstitüsü Dergisi, Özel Sayı, 1(4).

Azma, F. (2010). Qualitative Indicators for the Evaluation of Universities Performance. Procedia Social and Behavioral Sciences, 2, 5408-5411.

Babacan A., Kartal M. \& Bircan H. (2007). Cumhuriyet Üniversitesi'nin Etkinliğinin Kamu Üniversiteleri İle Karşılaştırılması: Bir VZA Tekniği Uygulaması, Cumhuriyet Üniversitesi, İktisadi ve İdari Bilimler Dergisi, 8(2), 97-114.

Badri, M.A. and Abdulla, M.H. (2004). Awards of Excellence in Institutions of Higher Education: An AHP Approach. International Journal of Educational Management, 18(4), 224-242.

Bahurmoz, A.M.A. (2003). The Analytic Hierarchy Process at Dar Al-Hekma, Saudi Arabia. Interfaces, 33(4), 70-78.

Balcı, A. (2015). Akademik teşvik ödeneği. 16 Ekim 2016 tarihinde <http:// www.abalci.com/2015/12/19/akademik-tesvik-odenegi/> adresinden erişildi.

Beğik. M., Hamurcu. M., ve Eren. T. (2017). Stok Kontrolde ABC Analizi Ve Analitik Ağ Süreci Yönteminin Isı Cihazları Firmasında Uygulanması. Kırıkkale Üniversitesi Sosyal Bilimler Dergisi, 7(1), 197-216.

Chen, J. K., \& Chen, I. S. (2010). Using a Novel Conjunctive MCDM Approach Based on DEMATEL, Fuzzy ANP, and TOPSIS as an Innovation Support System for Taiwanese Higher Education. Expert Systems with Applications, 37(3), 1981-1990.

Chen, S.J. Hwang C.L. (1992), Fuzzy Multiple Attribute Decision-Making: Methods and Applications, Springer, New York.

Chen, S., Yang, C., and Shiau, J. (2006). The application of balanced scorecard in the performance evaluation of higher education. The TQM Magazine, 18(2), 190-205.

Çeliksoy, E. (2009). Türkiye'de Devlet Üniversitelerinde Akademik Performans Kriterlerinin Belirlenmesi. Yayınlanmış Yüksek Lisans Tezi, Gazi Üniversitesi, Ankara.

Çürüksulu, G. (2015). Üniversitelerde Akademik Performans Yönetimi. Yayınlanmış Yüksek Lisans Tezi, İstanbul Medeniyet Üniversitesi, İstanbul.

Dağdeviren, M., Yavuz, S., \& Kılınç, N. (2009). Weapon Selection Using the AHP and TOPSIS Methods under Fuzzy Environment. Expert Systems with Applications, 36(4), 8143-8151.

Dinç, N., Hamurcu, M. ve Eren T., (2019). Ankara-Sivas Yüksek Hızlı Tren Hattında İstasyon Yerlerinin Seçiminde Çok Kriterli Karar Verme Destekli 0-1 Hedef Programlama Modeli. Demiryolu Mühendisliği, (9): 1-16.

Dinç, S., Hamurcu, M. ve Eren, T. (2018). Kentsel Ulaşım İçin Alternatif Tramvay Araçlarının Çok Kriterli Seçimi. Gazi Mühendislik Bilimleri Dergisi, 4(2), 124-135.

Doğan, G. (2017). Akademik Performans Odaklı Uluslararası Üniversite Sıralama Sistemlerinin Genel Sıralamalarına Ve Ölçütlerine Göre Değerlendirilmesi. Yayınlanmış Doktora Tezi, Hacettepe Üniversitesi, Ankara.

Erarslan, İ. (2015). Üniversitelerin Uluslararası Görünürlüğü: Akademik Performans ve Üniversite Marka Değeri İlişkisi. Beykent Üniversitesi Sosyal Bilimler Dergisi, 8(1), 37-47.

Eren, T., \& Özder, E. H. (2016). Çok Ölçütlü Karar Verme Yön- temleri İle Bir İçecek Firması İçin Tedarikçi Seçimi. In 4th International Symposium on Innovative Technologies in Engineering and Science (ISITES2016) 3-5 Nov 2016 Alanya/Antalya-Turkey.

Eren, T., Hamurcu, M., \& Alağaş, H. M. (2017). Çok Kriterli Karar Verme Yöntemleri ile Kırıkkale Yüksek Hızlı Tren İstasyon Yerinin Seçimi. 5th International Symposium on Innovative Technologies in Engineering and Science, 597-606.

Esen, M. ve Esen, D. (2015). Öğretim Üyelerinin Performans Değerlendirme Sistemine Yönelik Tutumlarının Araştırılması. Journal of Higher Education \& Science/Yüksekögretim ve Bilim Dergisi, 5(1), 52-67.

Esen, B. (2016). Akademik teşvik ödeneği nasıl ödenecek? 2 Eylül 2017 tarihinde <http://www.alosgk.com/2016/01/ akademik-tesvik-odeneginasl-odenecek.html> adresinden erişildi.

Eti, S. (2017). Üniversitelerdeki Akademik Üretkenliğe Etki Eden Faktörlerin İncelenmesi. Journal of Behavior at Work, 1(1), 67-73.

Gergin, R. E., \& Baki, B. (2015). Türkiye'deki Bölgelerin Lojistik Performanslarının Bütünleştirilmiş AHS ve TOPSIS Yöntemiyle Değerlendirilmesi. Business \& Economics Research Journal, 6(4).

Geyik, O., Tosun, M., Ünlüsoy, S., Hamurcu, M., \& Eren, T. (2016). Kitap Basımevi Seçiminde AHP ve TOPSIS Yöntemlerinin Kullanımı. Uluslararası Sosyal ve Eğitim Bilimleri Dergisi, 3(6), 106-126.

Geyik, O., Tosun, M., Ünlüsoy, S., Hamurcu, M., \& Eren, T. (2016). Kitap Basımevi Seçiminde AHP Ve TOPSIS Yöntemlerinin Kullanımı. Uluslararası Sosyal ve Eğitim Bilimleri Dergisi, 3(6), 106-126.

Göksu, İ. ve Bolat, Y. İ., (2017). Akademik Teşvik Uygulamasının illk Sonuçlarına Ait Değerlendirmeler. Yükseköğretim ve Bilim Dergisi/Journal of Higher Education and Science, 7(3), 441-452.

Grandzol, J.R. (2005). Improving the Faculty Selection Process in Higher Education: A Case Study for the Analytic Hierarchy Process. IR Application Using Advanced Tools, Techniques and Methodologies, 6, 2-12.

Gür, Ş., Hamurcu, M., \& Eren, T. (2016). Selection of Academic Conferences Based on Analytical Network Processes. Multiple Criteria Decision Making, 11, 51-62.

Gür, Ş., Hamurcu, M., \& Eren, T. (2016). Using Analytic Network Process And Goal Programming Methods For Project Selection in the Public Institution. Les Cahiers du MECAS, 13, 36-51.

Gür, Ş., Hamurcu, M., \& Eren, T. (2017). Ankara'da Monoray Projelerinin Analitik Hiyerarşi Prosesi Ve 0-1 Hedef Programlama İle Seçimi. Pamukkale Üniversitesi Mühendislik Bilimleri Dergisi, 23(4), 437-443.

Hamurcu, M., \& Eren, T. (2016). A Multicriteria Decision-Making for Monorail Route Selection in Ankara. International Journal of Industrial Electronics and Electrical Engineering, 4(5), 121-125.

Hamurcu, M., \& Eren, T. (2016). Using ANP- TOPSIS Methods For Route Selection Of Monorail in Ankara. 28th European Conference on Operational Research. Poznan, Polland.

Hamurcu, M., \& Eren, T. (2017). Raylı Sistem Projeleri Kararında Ahs-Hp Ve Aas-Hp Kombinasyonu. Gazi Mühendislik Bi- 
limleri Dergisi, 3(3), 1-13.

Hamurcu, M., \& Eren, T. (2017). Science Citation Index (SCI) Kapsamında Dergi Seçimi için Analitik Ağ Süreci Yönteminin Kullanılması. Harran Üniversitesi Mühendislik Dergisi, 2(2), 54-70.

Hamurcu, M., \& Eren, T. (2017). Selection of Monorail Technology by Using Multicriteria Decision Making. Sigma Journal of Engineering and Natural Sciences, 8(4), 303-314.

Hamurcu, M., Alağaş, H. M., \& Eren, T. (2017). Selection of rail system projects with analytic hierarchy process and goal programming. Sigma Journal of Engineering and Natural Sciences, 8(4), 291-302.

Hamurcu, M., Gür, Ş., Özder, E. H., \& Eren, T. (2016). A Multicriteria Decision Making For Monorail Projects with Analytic Network Process and 0-1 Goal Programming. International Journal Of Advances In Electronics And Computer Science (IJAECS), 3(7), 8-12.

Hamurcu, M., ve Eren, T., (2018). Kent İçi Ulaşım İçin Bulanık AHP Tabanlı VIKOR Yöntemi Ille Proje Seçimi. Engineering Sciences (NWSAENS), 13(3), 201-216.

Hamurcu, M. and Eren, T., (2018). Determination of Electric Bus Technology to Improve the Public Transportation using AHP-TOPSIS Methods. 29th European Conference on Operational Research (EURO2018), Valencia, Jully 8-11.

Hayrapetyan, L.R. and Kuruvila, M. (2011). An AHP-based Decision Support System for Faculty Evaluation. International Journal of Business. Marketing and Decision Sciences, 4(1), 68-79.

Hsieh, L-F., Chin, J-B. and Wu, M-C. (2006). Performance Evaluation for University Electronic libraries in Taiwan. The Electronic Library, 24(2), pp.212-224.

Göksu, A. (2008). Bulanık analitik hiyerarşik proses ve üniversite tercih sıralamasında uygulanması. Yayınlanmamış Doktora Tezi. Süleyman Demirel Üniversitesi Sosyal Bilimler Enstitüsü, Isparta.

Lii, F.a.T., Ketcham, A.F. and Hoffman, D. (1998). Personnel Evaluation with AHP. Management Decision, 36(10), 679-685.

Kalaycı, N. (2009). Yüksek Öğretim Kurumlarında Akademisyenlerin Öğretim Performansını Değerlendirme Sürecinde Kullanılan Yöntemler. Kuram ve Uygulamada Eğitim Yönetimi Dergisi, 15(4), 625-656.

Kaptanoğlu, D. ve Özok, A. F. (2006). Akademik Performans Değerlendirmesi İçin Bir Bulanık Model. iTÜ Dergisi, 5(1), 193-204.

Karaatlı, M., Ömürbek, N., Aksoy, E., \& Karakuzu, H. (2016). Turizm İşletmeleri İçin AHP Temelli Bulanık TOPSIS Yönetimi ile Tur Operatöru囚 Seçimi. Anadolu Üniversitesi Sosyal Bilimler Dergisi, 14(2), 53-70.

King, R. (1995). What is Higher Education for? Strategic Dilemmas for the Twenty-first Century University", Quality Assurance in Education, 3(4), 14-20.Koç, M. ve Yılmaz, E. (2010). WEBOMETRIC ve ARWU Tarafından Yapılan Üniversite Sıralamalarındaki Performansın Artırılmasına Yönelik Akademisyen Görüşleri. SDU International Journal of Technological Science, 2(3), 17-30.

Kutlar A., Gülcü A. ve Karagöz Y., (2004). Cumhuriyet Üniversitesi Fakültelerinin Performans Değerlendirmesi. C.Ü. İktisadi ve İari Bilimler Dergisi, 5(2), 137-154.
Küçük, M. ve Karabacak, N. (2017). An Evaluation on the Application of Academic Encouragement in Turkish Higher Education. Turkish Journal of Teacher Education, 6(2), 124-157.

Lee S.H., (2010). Using Fuzzy AHP To Develop Intellectual Capital Evaluation Model For Assessing Their Performance Contribution In A University. Expert Systems With Applications, 37, 4941-494.

Lee, S. H., (2010). Using Fuzzy AHP to Develop Intellectual Capital Evaluation Model for Assessing Their Performance Contribution in a University. Expert Systems with Applications, 37, 4941-4947.

Lupo T., (2013). A Fuzzy Servqual Based Method For Reliable Measurements Of Education Quality In Italian Higher Education Area. Expert Systems With Applications, 40, 70967110.

Mahdi B. A. M., (2011). Bir Mühendislik Fakültesi Bölümlerinin Akademik Performanslarının Değerlendirilmesi. Yayınlanmış Yüksek Lisans Tezi, Gazi Üniversitesi, Ankara.

Mautner, G (2005), The Entrepreneurial University: A Discursive Profile of A Higher Education Buzzword. Criticak Discourse Studies, 2(2), 95-120.

Murat, G. ve Çevik, E. İ. (2008). Iç Paydaş Olarak Akademik Personel Memnuniyetini Etkileyen Faktörlerin Analizi: Zonguldak Karaelmas Üniversitesi Örneği. ZKÜ Sosyal Bilimler Dergisi, 4(8), 1-18.

Okumuş, K. ve Yurdakal, ì.H. (2017). Akademisyenlerin Akademik Teşviğe Ilişkin Görüş ve Düşünceleri. Journal of Academic Social Science Studies. 58, 145-156.

Ömürbek, N., Karaatlı, M. ve Yetim, T. (2014). Analitik Hiyerarşi Sürecine Dayalı TOPSIS ve VIKOR Yöntemleri İle ADIM Üniversitelerinin Değerlendirilmesi. Selçuk Üniversitesi Sosyal Bilimler Enstitüsü Dergisi, 189-207.

Ömürbek, N., Tunca, M. Z., Özcan, A., Yıldız, E., \& Karataş, T. (2016). AHP TOPSIS Yönteminin Tıpta Uzmanlık Alan Seçiminde Kullanımı. Akdeniz Üniversitesi İktisadi ve İdari Bilimler Fakültesi Dergisi, (33), 201-219.

Özcan, E. C., Ünlüsoy, S., \& Eren, T. (2017). A Combined Goal Programming-AHP Approach Supported with TOPSIS for Maintenance Strategy Selection in Hydroelectric Power Plants. Renewable and Sustainable Energy Reviews, 78, 1410-1423.

Özden Ü.H., (2008). Veri Zarflama Analizi (VZA) ile Türkiye'deki Vakıf Üniversitelerinin Etkinliğinin Ölçülmesi. İstanbul Üniversitesi İşletme Fakültesi Dergisi, 37(2), 167-185.

Qiang, Chen Shi. (2014). Study on Performance Evaluation of Digital Resources in College Library Based on Fuzzy Analytic Hierarchy Process. Journal of Chemical and Pharmaceutical Research, 6(5), pp.1122-1127, 2014.

Rouyendegh, B. D. and Erol, S. (2009). A DEA - ANP hybrid Algorithm Approach to Evaluate a University's Performance. International Journal of Basic \& Applied Sciences IJBAS, 9(10), 115-129.

Saka, Y. ve Yaman, S. (2011). Üniversite Sıralama Sistemleri; Kriterler ve Yapılan Eleştiriler. Journal of Higher Education \& Science/Yüksekögretim ve Bilim Dergisi, 1(2), 72-79.

Samut, P. K. (2014). İki Aşamalı Çok Kriterli Karar Verme ile Performans Değerlendirmesi: AHP ve TOPSIS Yöntemlerinin Entegrasyonu. Anadolu Üniversitesi Sosyal Bilimler Dergisi, 14(4), 57-67. 
Samut, P. K. (2016). İki Aşamalı Çok Kriterli Karar Verme Ile Performans Değerlendirmesi: AHP ve TOPSIS Yöntemlerinin Entegrasyonu. Anadolu Üniversitesi Sosyal Bilimler Dergisi, 14(4), 57-67.

Saaty, T. L. (2004). Decision Making - the Analytic Hierarchy and Network Processes (AHP/ANP). Journal of Systems Science And Systems Engineering, 13(1), 1-35.

Saaty, T.L. (1980) The Analytic Hierarchy Process, New York: McGraw-Hill International Book Company.

Simmons, J. (2002). An "expert witness" perspective on performance appraisal in universities and colleges. Employee Relations, 24(1), 86-100. Siew, Renard Y. J., (2015), Case study of an Australian residential college, Journal of Facilities $\mathrm{Ma}$ nagement, Vol. 13 Issue 4, pp.391-398.

Soba M., (2012). Üniversite Öğrencilerinin Performanslarının Akademisyenler Tarafından Analitik Hiyerarşi Süreci ile Değerlendirilmesi (Uşak Üniversitesi Örneği). Elektronik Sosyal Bilimler Dergisi, 11, (42), 368-381.

Supçiller, A. A., \& Deligöz, K. (2018). Tedarikçi Seçimi Probleminin Çok Kriterli Karar Verme Yöntemleriyle Uzlaşık Çözümü. Uluslararası İktisadi ve İdari İncelemeler Dergisi, 355-368.

Şahin, F., Tabak, B. Y. ve Tabak, H. (2017). Motivasyon Kuramları Bağlamında Akademik Teşvik Ödeneği Uygulamasının Değerlendirilmesi. Journal of Higher Education \& Science/ Yüksekögretim ve Bilim Dergisi, 7(2), 403-410.

Taş, M., Özlemiş, Ş., Hamurcu, M., \& Eren, T. (2017). Analitik Hiyerarşi Prosesi ve Hedef Programlama Karma Modeli Kullanılarak Monoray Projelerinin Seçimi. Harran Üniversitesi Mühendislik Fakültesi Dergisi, 2(2), 24-34.

Taş, M., Özlemiş, Ş., Hamurcu, M., \& Eren, T. (2017). Ankara'da AHP ve PROMETHEE Yaklaşımıyla Monoray Hat Tipinin Belirlenmesi. Ekonomi, İşletme, Siyaset ve Uluslararası İlişkiler Dergisi, 3(1), 65-89.

Taylor,J. (2001). The impact of performance indicators on the work of university academics: Evidence from Australian universities. Higher Education Quarterly, 55(1), 42-61.

Todorevic, Z., McNaughton RB., and Guild P., (2011). ENTRE-U: An Entrepreneurial Orientation Scale for Universities. Technovation, 31, 128-137.

Torağay, O. ve Arıkan, M. (2015). Delfi Ve TOPSIS Yöntemleri Kullanılarak Bir Mühendislik Fakültesindeki Bölümlerin Akademik Performans Değerlendirmesi. Cumhuriyet Üniversitesi İktisadi ve İdari Bilimler Dergisi, 16(2), 13-28.

Turhan, M. ve Erol, Y. C. (2017). Akademisyenlerin Akademik Teşvik Ödeneğine İlişkin Görüşleri. İnönü Üniversitesi Eğitim Fakültesi Dergisi, 18(3), 281-296.

Umayal Karpagam, P.L. and Suganthi, L. (2010). A Strategic Framework for Managing Higher Educational Institutions. Advance in Management, 3(10), 15-21.

Uslu, A., Kızıloğlu, K., İşleyen, S. K., \& Kâhya, E. (2017). Okul Yeri Seçiminde Coğrafi Bilgi Sistemine Dayalı AHP-TOPSIS Yaklaşımı: Ankara İli Örneği. Politeknik Dergisi, 20(4), 933-943.

Uzgören E. \& Şahin G., (2013). Dumlupınar Üniversitesi Meslek Yüksekokulları'nın Performanslarının Veri Zarflama Analizi Yöntemiyle Ölçümü. Uluslararası Yönetim İktisat Ve İşletme Dergisi, 9(18), 91-110.

Wu H.Y., Chen J.K., Chen S. \& Zhuo H.H., (2012). Ranking Uni- versities Based On Performance Evaluation by A Hybrid MCDM Model. Measurement, 45, 856-880.

Yeh, C. H. (2002). A Problem-based Selection of Multi-attribute Decision-making Methods. International Transactions in Operational Research, 9(2), 169-181.

Yokuş, G., Ayçiçek, B. ve Kanadlı, S. (0000). Akademisyen görüşleri doğrultusunda yükseköğretimde performansa dayalı akademik teşvik sisteminin incelenmesi. Yükseköğretim Dergisi, doi:10.2399/yod.18.007.

Yu-Jen Tsen (2013), An exploratory analysis in the construction of college performance indices, International Journal of Organizational Innovation, Vol. 5 Issue 3, p.98-132.Yüksel, M. (2015). Performans Değerlendirmesine Çok Ölçütlü Bütünleşik Bir Yaklaşım. Gazi Üniversitesi MühendislikMimarlık Fakültesi Dergisi, 30(3), 429-441.

Zhou, P., Ang, B. W., Poh, K. L., 2006. Decision Analysis in Energy and Environmental Modeling: An Update. Energy, 31 (14), 2604-2622. 